\title{
Ildır Körfezi güneyindeki bölgenin Neojen stratigrafisi Çeşme Yarımadası, Batı Anadolu
}

\author{
Neogene stratigraphy of the region in the south of Ildir Bay, Çeşme Peninsula, \\ Western Anatolia
}

\section{Fikret GÖKTAŞ}

119/8 Sok., 6/5, K.3, D.9, Evka-3, Bornova, IZMIR

(e-posta: fikretgoktas50@gmail.com)

\section{ÖZ}

Çeşme Yarımadası'nın kuzeydoğu kıyı kesimindeki karasal Neojen tortullaşmasının başlangıcı, alt dokanağ1 yüzeylemeyen Şifne formasyonu ile temsil edilir. Stratigrafik konumuyla Erken Miyosen yaşlı olduğu düşünülen istifin gözlenebilen en üst bölümü, tatlı su algli gölsel kireçtaşlarından oluşur. Armağandağ1 volkanizmasının erken ürünleri olan felsik ignimbiritlerin kireçtaşı platformu üzerine yerleşimiyle Şifne formasyonu tortullaşması sona erer.

Çeşme Yarımadası'nda geç Erken Miyosen-erken Orta Miyosen kalkalkalen volkanizmayı yansıtan Armağandağı grubu volkanitlerinin çalışma alanındaki uzantıları ağırlıklı olarak volkanoklastik fasiyeslerdedir. Volkanoklastik topluluk, altta felsik ignimbiritlerin simgelediği Alaçatı tüfü ve üstte ignimbirit, bloklu kül akması ve lahar fasiyeslerindeki andezitik volkanizma türevlerinden oluşan Reisdere volkanoklastiklerinden oluşur. Alaçatı tüfü, Şifne formasyonu ile Reisdere volkanoklastikleri arasında konumlanmıştır. Zeytineli formasyonu, Armağandağı grubu volkanitlerinin lav fasiyesini temsil eder.

Neojen öncesi temel kayalarını açılı uyumsuzlukla üstleyen Ildır formasyonu ile üst kesimi onunla girik olan Armağandağı volkanitleri, erken Orta Miyosen tortullaşması ve kalkalkali volkanizmasını yansıtır. Altta çamurtaş1-kumtaşı ardalanması, üstte ise killi kireçtaşından oluşan gölsel Ildır formasyonu, alt kesiminde fan delta ortamında çökelmiş Belentepe üyesini içerir. Belentepe üyesi içine sinsedimanter

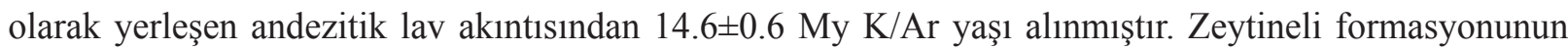
uzantısı olan bu lav düzeyinin yaşı, Armağandağı volkanizmasının erken Orta Miyosen'de devam ettiğini belgeler.

Anahtar kelimeler: Çeşme Yarımadası, K/Ar jeokronolojisi, Neojen stratigrafisi, Neojen volkanizması 


\section{ABSTRACT}

The beginning of Neogene terrestrial sedimentation in the northeastern coastal part of the Çeşme Peninsula is represented by the Şifne formation, which its lowermost part is not exposed. The age of succession evaluated as Early Miocene stratigraphically and its uppermost observable part consists of lacustrine limestone bearing fresh water algae. The ignimbrite flows, early products of Armağandă̆l volcanism, stopped and ended the sedimentation of Şifne formation.

The Armă̆andă̆l volcanics represents the late Early Miocene-early Middle Miocene calcalkaline volcanism in the Çeşme Peninsula. The tongues of the volcanism in the study area are mainly composed of volcaniclastics. The volcaniclastic assemblage comprises felsic ignimbrites at the lower part namely Alaçatı tuff, and andesitic ignimbrite, blocky ash flow deposits and lahars of Reisdere volcaniclastics at the upper part. Alaçatı tuff is located between Şifne formation and Reisdere volcaniclastics. The Zeytineli formation represents the lavas of the Armağandere group.

The Ildir formation overlies the pre-Neogene basement rocks with an angular unconformity and laterally grades into the upper part of the Armağandă̆l volcanics. They represent the early Middle Miocene sedimentation and calcalkaline volcanism. The lacustrine Ildir formation is composed of mudstonesandstone alternation in the lower part and clayey limestone at the upper part, and comprises the Belentepe member deposited in a fan-delta environment in the lower part. A synsedimentary lava level in

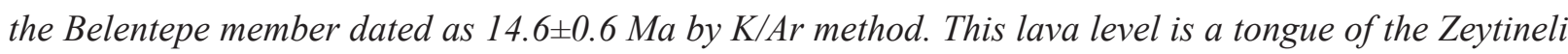
formation, and its age shows that the activity of Armağandă̆ Miocene.

Key Words: Çeşme Peninsula, K/Ar geochronology, Neogene stratigraphy, Neogene volcanism

\section{GİRIS}

Çeşme Yarımadası kuzeyinde, Çeşme ilçesinin Şifne Mahallesi ile Ildır köyü arasındaki alanda yayılım gösteren karasal Neojen kaya birimlerini tanımlayarak stratigrafi düzenini kurmak ve bölgeyi 1:25.000 ölçekte haritalamak amaciyla gerçekleştirilen bu çalışma, Göktaş (2010)'ta daha geniş değerlendirilen jeolojik etütlerin bir bölümünü kapsar (Şekil 1). Araştırmanın başlıca gerekçesi, daha önce çalışılmamış olan bu bölgedeki Miyosen çökelimini tanıtmak ve yaşıt volkanizmayla ilişsisini ortaya koymaktır.

Karaburun Yarımadası genelinde Kalafatçıŏlu (1961) ile başlayan jeolojik etütlerin başlıcaları, ağırlıklı olarak Neojen öncesi kaya birimlerine yöneliktir (Ayrıntılı liste, Çakmakoğlu ve Bilgin, 2006'da verilmiştir).
Çeşme Yarımadası'nı kapsayan az sayıdaki Neojen çalışmaları magmatizma (Innocenti ve Mazzuoli, 1972; Borsi vd.,

1972; Türkecan vd., 1998; Kaçmaz ve Köktürk, 2004; Helvacı vd., 2009), hidrojeolojijeotermal enerji (Gemici ve Filiz, 2001) üzerinedir. Innocenti ve Mazzuoli (1972), Karaburun Yarımadası'ndaki Neojen volkanitlerinin petrokimyasal özelliklerini inceledikleri öncü çalışmalarında, 'Alaçatı masifi'nin kalkalkalen latit-andezitlerden oluştuğunu belirtir. Borsi vd. (1972), Alaçatı GD'sundaki andezitten 18,2 My ve Ildır köyü yakınlarında yüzeyleyen dasitten 17,0 My K/Ar yaşları almışlardır. Kaçmaz ve Köktürk (2004), Alaçatı çevresindeki 'silisik vitrik tüflerin' (bu çalışmada tanımlanan Alaçatı tüfü) jeokimyasal ve mineralojik özelliklerini 
incelemişler, kısmi alterasyona uğramış kesimlerde otijenik zeolitleşmenin geliştiğini belirtmişlerdir. Türkecan vd. (1998) ile Helvacı vd. (2009)'nin Karaburun Yarımadası için önerdikleri bireşimsel stratigrafiler radyometrik yaşlara göre kurgulanmış ve Neojen tortullaşması ile volkanizmasının alttan üste yanal ilişskili gelişim gösterdiği kabul edilmiştir. Çeşme Yarımadası'nın Neojen jeolojisini bütünsel olarak ele alan tek çalışma Göktaş (2010)'a aittir. Bu çalışmaya göre karasal Neojen tortullaşması, Alt-Orta Miyosen yaşı 'Çeşme grubu' ve açılı uyumsuzlukla üstte yer alan Üst Miyosen yaşl1 'Kaştepe grubu' ile simgelenir. Egemen gölsel Çeşme grubu, alttan üste 'Şifne', 'Ovacık' ve 'Çiftlik' formasyonlarından oluşur. Neojen tortullaşmasının ilk istifini oluşturan Şifne formasyonunun stratigrafik tabanı, Çeşme Yarımadası genelinde yüzeylememiştir. Geç Erken Miyosen-erken Orta Miyosen döneminde etkinlik gösteren kalkalkali volkanizma ürünleri 'Armağandağı volkanitleri' kapsamında incelenmiştir. 'Reisdere volkanoklastikleri', altta asidik piroklastikleri ve üstte yer alan genellikle ortaç volkanoklastikleri kapsar. Formasyonun alt bölümündeki asidik piroklastikler (Alaçatı tüfü), Çeşme Yarımadası'ndaki geniş yayılım alanları içinde Şifne ve Ovacık gölsel istiflerini ayırır. Volkanoklastik istifin üst bölümü, baskın olarak andezitik volkanizma türevi piroklastikepiklastik yoğunluk akıntısı düzeylerinden yapılıdır. Andezit ve az oranda dasit bileşimli lav topluluğunu kapsayan Zeytineli formasyonu, Reisdere volkanoklastiklerine alttan üste yanal girik kabul edilmiştir. Göktaş (2014a,b)'a göre Karaburun Yarımadası'nın kuzey bölümündeki karasal Neojen istifi, altta 'Karaburun grubu' (AltOrta Miyosen) ve açılı uyumsuzlukla üstte yer alan 'Eşendere grubu' (Üst Miyosen-Alt Pliyosen) çökellerinden oluşur. Üç evreli 'Karaburun volkanitleri', Karaburun grubunun egemen gölsel istifine yanal giriktir. (Şekil 2).

\section{GENEL JEOLOJİ}

Karaburun Yarımadası'ndaki karasal Tersiyer tortullaşması ve volkanizması, Neojen kaya birimleri ile simgelenir. Bornova Fliş Zonu kayalarının tektonik yerleşimi ile Erken Miyosen havza oluşumu arasında geçen süre boyunca bölgenin deformasyona uğradığ 1 ve aşındığ kabul edilir. Çeşme Yarımadası'ndaki Alt-Orta Miyosen kaya birimleri ile Çakmakoğlu ve Bilgin (2006)'de tanımlanan Paleozoyik ve Mesozoyik yaşlı temel kayaları arasındaki dokanaklar açılı uyumsuz ya da tektoniktir.

Türbiditik özellikteki Dikendağ1 formasyonu (Siluriyen-Karbonifer) ile kırıntılı ve karbonat kayalardan oluşan Alandere formasyonu (Başkiriyen-Vizeyen), denizel Paleozoyik çökelimini simgeler. Paleozoyik temeli açılı uyumsuzlukla üstleyen Mesozoyik sekansının tabanındaki Gerence formasyonu, Skitiyen yaşlı transgresif çökellerle başlar ve Anisiyen'de karbonat kaya egemen derin deniz çökelleriyle devam eder. Ladiniyen döneminin neritik karbonat çökelimini yansıtan Camiboğazı formasyonu, geçişli olarak Gerence formasyonu üzerine gelir. Geç Triyas'ta sığ denizel çökellerle (Güvercinlik formasyonu) devam eden Mesozoyik çökelimi, Jura'da neritik karbonatlarla (Nohutalan formasyonu) temsil edilir (Şekil 3).

Karaburun Yarımadası'nın kuzey bölümünde Alt Miyosen yaşlı yelpaze deltası ve göl çökelleri ile onların üzerinde yer alan Yaylaköy volkanitlerinin yayılımı bulunur (Innocenti ve Mazzuoli, 1972; Borsi vd., 1972; Türkecan vd., 1998; Aras vd., 1999; Helvacı vd., 2009; Çakmakoğlu vd., 2013). Yarımadanın kuzey kıyılarında egemen gölsel Alt-Orta Miyosen çökelleri, kuzeydoğusunda ise Orta-Üst Miyosen çökelleri yüzeyler. Yarımadanın K-KD kesiminde Göktaş (2014a,b) tarafindan tanımlanan Karaburun volkanitleri, Alt-Orta Miyosen yaşlı Karaburun grubu gölsel çökellerine yanal giriktir. Gülbahçe fayı (Emre vd., 
2005) ile Urla çöküntüsünden ayrılan Karaburun yükseltisinin güney bölümünde, kalkalkali riyodasit-dasit-andezit bileşim aralığındaki volkanitlerden yapılı 'Kocadağ' ve 'Armağan Dağı’ volkanik kompleksleri yer alır (Innocenti ve Mazzuoli, 1972; Borsi vd., 1972; Türkecan vd., 1998; Helvacı vd., 2009). Armağandağ1 volkanizması, Çeşme Yarımadası'ndaki egemen gölsel geç Erken- erken Orta Miyosen çökelimiyle yanal ilişkili gelişim göstermiştir (Göktaş, 2010).

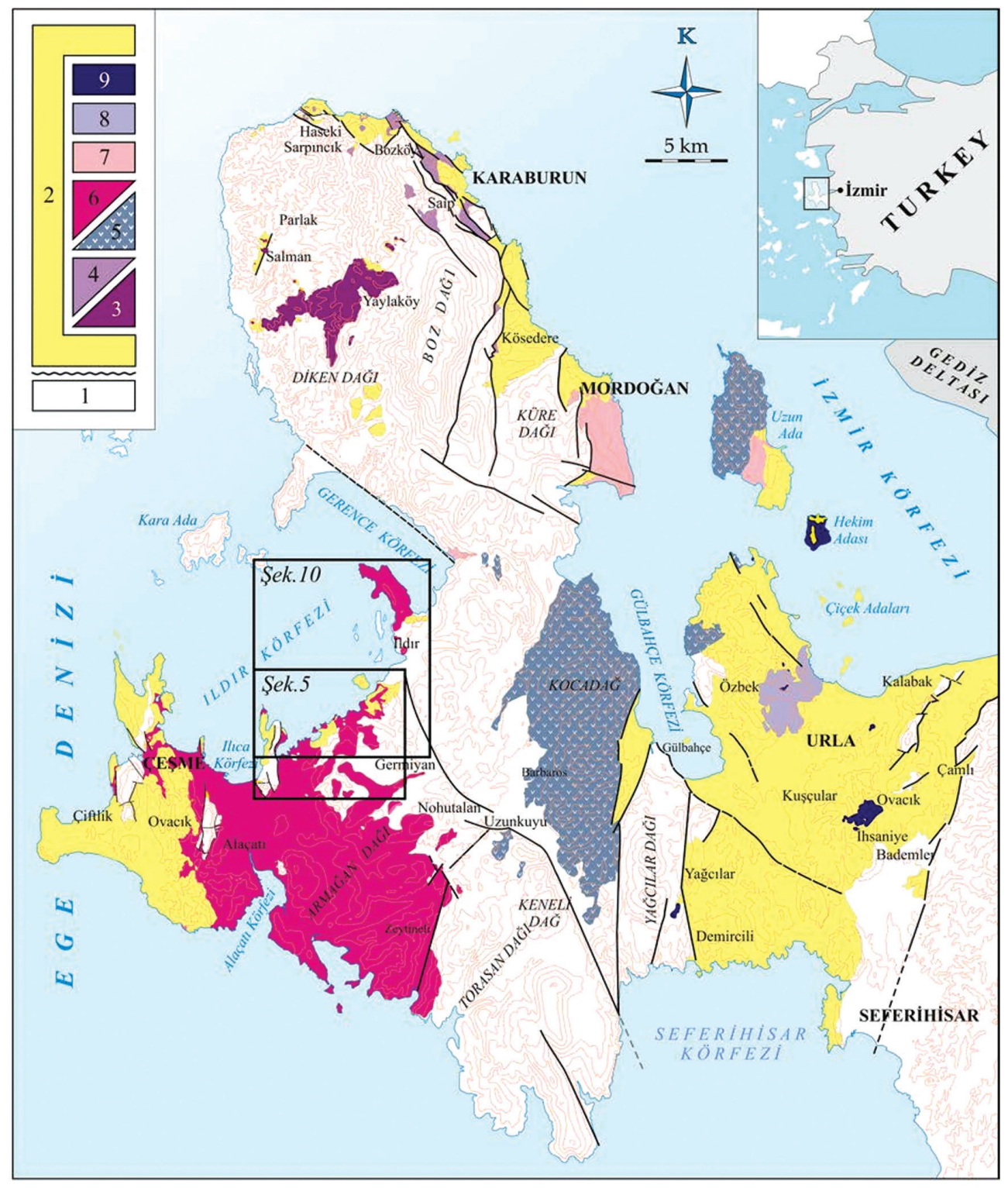

Şekil 1. Çalışma alanının Karaburun Yarımadası'ndaki konumu. 1. Neojen öncesi temel kayaları, 2. Neojen çökelleri, 3. Yaylaköy Volkanitleri, 4. Karaburun Volkanitleri, 5. Kocadağ Volkanitleri, 6. Armağandağ Volkanitleri, 7. Foça Tüfü, 8. Menteş Volkanitleri, 9. Ovacık Bazaltı.

Figure 1. Situation of study area in the Karaburun Peninsula. 1. Pre-Neogene basement rocks, 2. Neogene sediments, 3. Yaylaköy Volcanics, 4. Karaburun Volcanics, 5. Kocadă̆ Volcanics, 6. Armağandağ Volcanics, 7. Foça Tuff, 8. Menteş Volcanics, 9. Ovacık Basalt. 


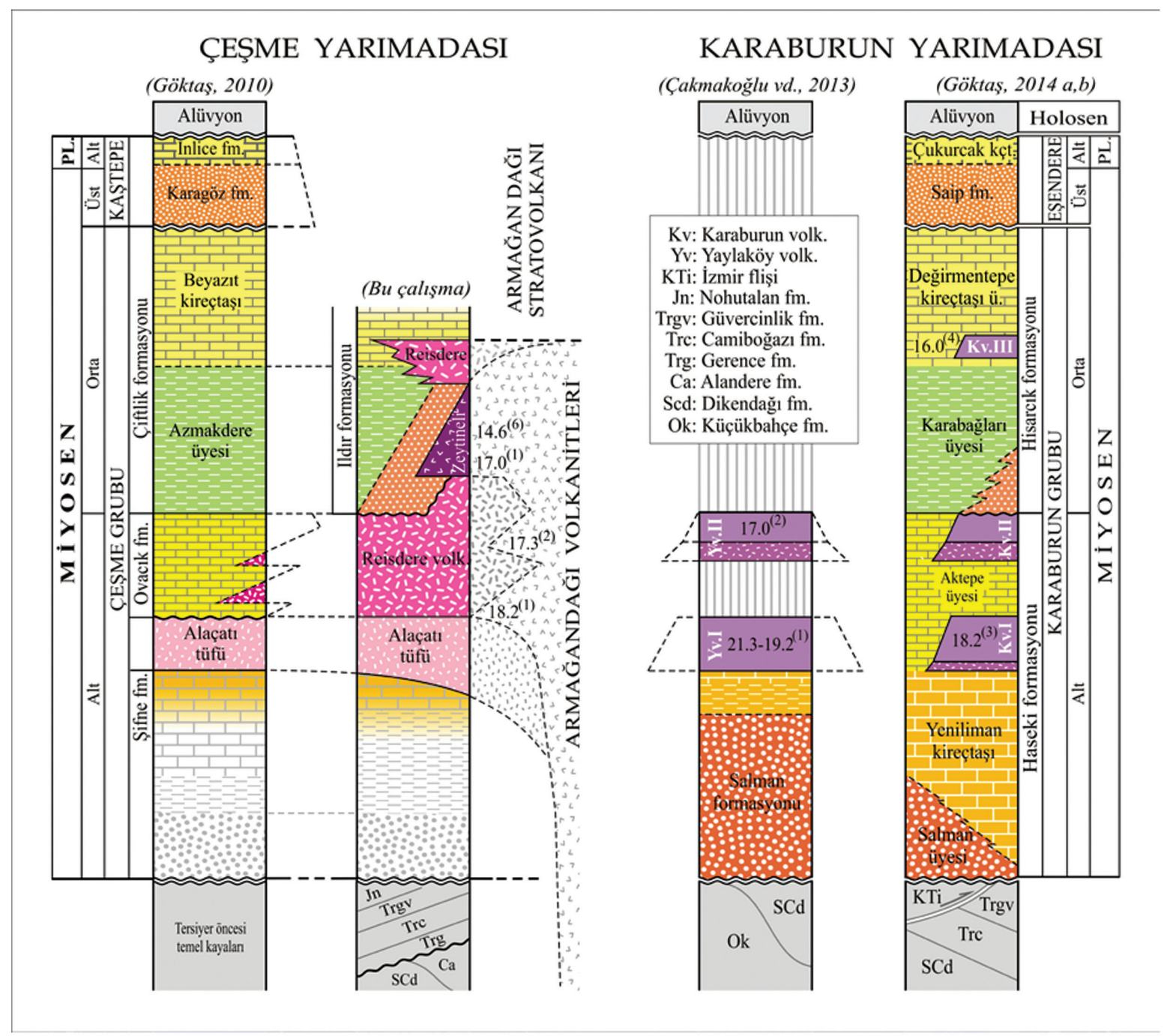

Şekil 2. Karaburun Yarımadası'ndaki Neojen kaya birimleri için önerilen genelleştirilmiş stratigrafilerin karşılaştırılması. Radyometrik yaşlar: ${ }^{(1)}$ Borsi vd. (1972), (2) Helvacı vd. (2009), ${ }^{(3)}$ Göktaş (2014a), ${ }^{(4)}$ Göktaş (2014b), ${ }^{(5)}$ Bu çalışma.

Figure 2. Correlation of suggested generalized stratigraphies of the Neogene lithounits in the Karaburun Peninsula. Radiometric ages: (1) Borsi et al (1972), (2) Helvacr et al (2009), (3) Göktaş (2014a), (4) Göktaş (2014b), (5) This study. 


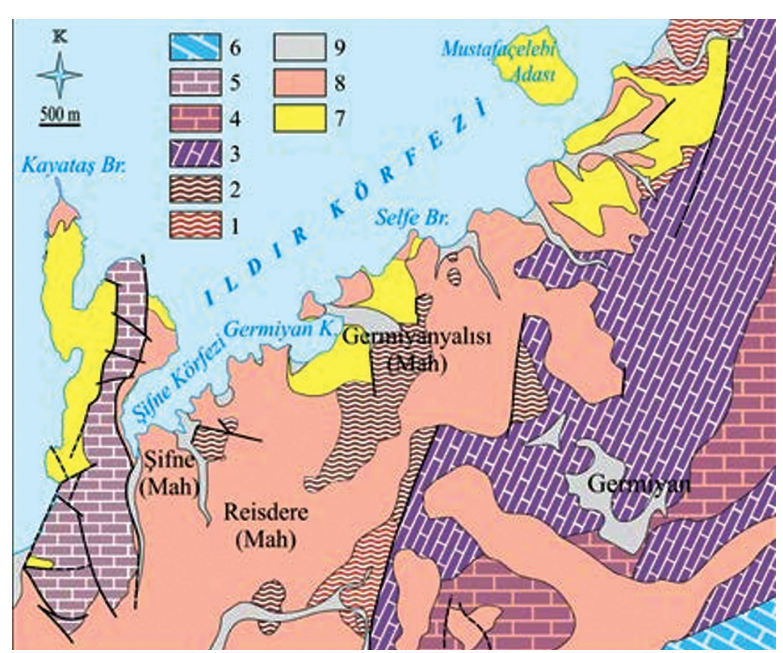

Şekil 3. Çalışma alanında yüzeyleyen Paleozoyik ve Mesozoyik yaşlı temel kaya birimlerinin jeoloji haritası (Çakmakoğlu ve Bilgin, 2006'dan değişiklikle). 1. Dikendağı Fm. (Karbonifer- Siluriyen), 2. Alandere Fm. (Başkiriyen-Viseyen), 3. Gerence Fm. (Anisiyen-Skitiyen), 4. Camiboğazı Fm. (Ladiniyen), 5. Güvercinlik Fm. (ResiyenKarniyen), 6. Nohutalanı Fm. (MalmLiyas), 7. Alt- Orta Miyosen çökelleri, 8. Armağandağı Volkanitleri, 9. Alüvyon.

Figure 3. Geologic map of the Paleozoic and Mesozoic basement rocks exposed in the study area (Modified after Çakmakoğlu and Bilgin, 2006). 1. Dikendağ Fm. (CarboniferousSilurian), 2. Alandere Fm. (BashkirianVisean), 3. Gerence Fm. (AnisianSkytian), 4. Camiboğazı Fm. (Ladinian), 5. Güvercinlik Fm. (Resian-Carnian), 6. Nohutalanı Fm. (Malm-Lassic), 7. LowerMiddle Miocene deposits, 8. Armağandağı Volcanics, 9. Alluvium.

\section{STRATIGRAFI}

Neojen Tortullaşması Çalışma alanında yüzeyleyen karasal Neojen istifi, gölsel Şifne formasyonu (Erken Miyosen) ve alüviyal-gölsel çökellerden oluşan Ildır formasyonu (Orta Miyosen) ile simgelenir (Şekil 4).

\section{Şifne Formasyonu}

Algal kireçtaşlarıyla simgelenen Şifne formasyonu, Çeşme Yarımadası'nda yüzeyleyen en yaşlı Neojen birimidir. İlk kez Göktaş (2010) tarafından 'Çeşme grubu' kapsamında tanımlanan birimin adı, Germiyanyalısı Mahallesi'nin 5 km batısında bulunan Şifne Mahallesi'nden alınmıştır. Çalışma alanında en çok 40 metrelik en üst bölümü gözlenebilen gölsel istif, Şifne Körfezi'nin bat1 kıyılarında yüzeyler (Şekil 5).

Tortul istif, genel olarak tatlı su algli kireçtaş1 ve az oranda ince-orta katmanlı mikritik kireçtaşından oluşur. Tortul istifin en üst bölümündekialglikireçtaşlarının altında, alglikireç taş1-killi kireçtaşı-marn-kiltaşı ardışı istifi yer alır. Tatlı su alg kapsamı ondülasyonlu/düzlemsel paralel laminalı stratiform stromatolitler ile temsil edilir. Algal laminalara koşut gelişmiş fenestral boşluklar olağandır. Az oranda bulunan dallı (branched) algler, yeniden işlenerek parçalanmış ve kireçtaşı katmanları içinde desimetrik kalınlıklarda biyosparitik düzeyler oluşturmuştur. Birimi üstleyen Alaçatı tüfünün hemen altındaki kireçtaşı katmanları bölümsel/tümsel silisleşmiştir ve siyah/kahve renkli elipsoidal çört nodülleri kapsar.

Çeşme Yarımadası genelinde gölsel çökellerle temsil edilen Şifne formasyonu, karasal Neojen tortullaşmasının başlangıcını simgeler (Göktaş, 2010). Alaçatı tüfünü simgeleyen felsik ignimbiritler, konsolide olmamış algli kireçtaşı platformu üzerine yerleşmiş ve Şifne formasyonu çökelimi sona ermiştir. İgnimbiritlerin, çökelmekte olan kireçtaşları üzerine yerleştiği, içlerinde yer alan yumuşak çökel deformasyonuna uğramış algli kireçtaşı parçalarından (rip-up clasts) anlaşılmaktadır.

Şifne formasyonunu yaşlandırabilecek biyokronolojik veri bulunmamaktadır. Çeşme Yarımadası'nın Neojen stratigrafisinde, Alaçatı tüfü üzerindeki Zeytineli formasyonu andezitlerinden önceki çalışmalarda alınan

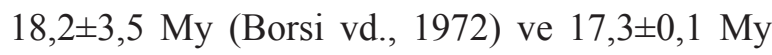
(Helvacı vd., 2009) yaşlarına dayanılarak, Şifne 
formasyonunun geniş anlamda Erken Miyosen'de çökeldiği kabul edilmiştir (Şekil 4).

Çalışma alanında Alaçatı tüfü altından yüzeyleyen Şifne formasyonu, Göktaş (2010)'ta değerlendirilen jeotermal sondaj verilerine göre olası fan delta çökelleriyle başlar ve esas olarak gölsel çökellerden oluşur. İstifin çalışma alanında yüzeyleyen bölümü, ince kırıntılı gölsel çökellerden tatlı su algli kireçtaşlarına derecelenen düşük enerjili sı̆̆ gölsel tortullaşmayı yansıtır.

Şifne formasyonu, Karaburun Yarımadası kuzeyinde Göktaş (2014a) tarafından tanımlanan 'Yeniliman kireçtaşı' ile deneştirilebilir. Urla havzas1 ve kuzeyinde yer alan adalar topluluğunda, Şifne formasyonunun kaya-stratigrafik karşılığ bulunmaz (Göktaş, 2011;2016). Birimin Foça Yarımadası'ndaki zaman-stratigrafik korelanları 'Zeytindağ formasyonu' (Kaya, 1979) kapsamındadır.

\section{Ildır Formasyonu}

Orta Miyosen tortullaşmasını yansıtan Ildır formasyonu (Göktaş, 2010), çakılttaş1, kumtaş1, çamurtaş1, kireçtaşı topluluğundan oluşur ve Armağandağ1 volkanitlerinin yanal uzantılarını kapsar (Şekil 4). Tortul istifin alt bölümünü oluşturan çakıltaşı egemen Belentepe üyesi, havza kenarı çökelimini simgeler.

Ildırformasyonununstratigrafik pozisyonu ve kayatürü bileşimi, Çeşme Yarımadası'nın batısında tanımlanan 'Çiftlik formasyonu' (Göktaş, 2010) ile korelasyonu düşündürür. Ancak Çiftlik formasyonunun tabanında, Belentepe üyesi ile karşılaştırılabilecek alüviyal çökeller bildirilmemiştir. Karaburun Yarımadası kuzeyinde Göktaş (2014a,b) tarafından tanımlanan 'Hisarcık formasyonu', Ildır formasyonunu bütünüyle karşılar (Şekil 2). Urla havzası ile İzmir Körfezi adalarında tanımlanan Orta Miyosen yaşlı 'Urla grubu' (Göktaş, 2016), Ildır formasyonu ile deneştirilebilecek çökel toplulukları kapsar.

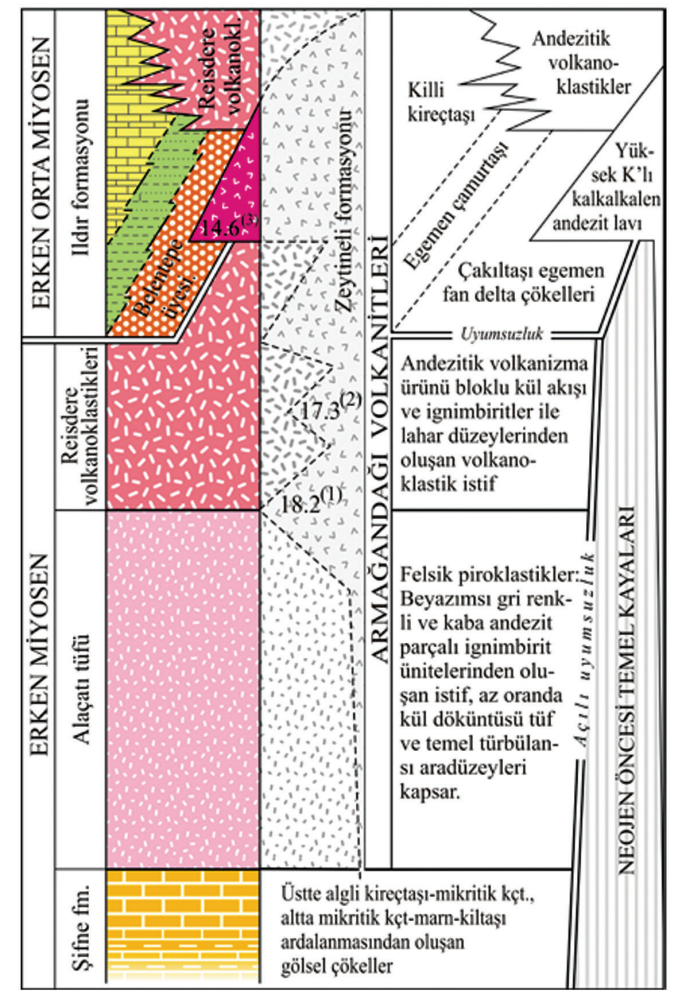

Şekil 4. Çalışma alanında yüzeyleyen Miyosen kaya birimlerinin genelleştirilmiş stratigrafisi. (1) Borsi vd. (1972), (2) Helvacı vd. (2009), (3) Bu çalışma.

Figure 4. Generalized stratigraphy of the Miocene rock units in the study area, (1) Borsi vd. (1972), (2) Helvacl vd. (2009), (3) This study.

Reisdere

volkanoklastiklerinin oluşturduğu yerel örtü, Ildır Körfezi'nin oluşumuyla havzanın büyük ölçüde denize gömülmesi ve günümüze kadar süren aşınma nedeniyle, istifin en çok $40 \mathrm{~m}$ kalınlığındaki bir bölümü gözlenir. Kireçtaşlarının altında yer alan gölsel çamurtaşı egemen istifin ancak birkaç metrelik bölümü yüzeylemiştir.

Esas olarak kireçtaşından oluşan istifin gözlenebilen en alt bölümü, 3-30 cm arası düzlemsel paralel katmanlı ve yüksek karbonatlı çamurtaşı, ince-orta taneli kumtaşı düzeylerinden oluşur. Sarımsı-yeşilimsi gri ve soluk pembemsi-bej renkler yaygındır. Çamurtaşı 
düzeyleri içinde yer alan ince-orta taneli kumtaşı arakatmanlarından bazılarında, yanal bağlantıl1/ bağlantısız merceksel katmanlı ripıllar gözlenir. Olası kuruma çatlaklarına, doğru derecelenmiş kumtaşı katmanlarına ve Fe konkresyonlarına seyrek olarak rastlanır (Şekil 6A). Soluk kırmızı renkli, masif ve kötü boylanmış çamur akması ara düzeyleri, Belentepe üyesinin sualtı çökelimine katılan yanal uzantıları olarak yorumlanmıştır. (Şekil 6B). Dar bir aralıkta ardalanarak ince kırıntılı çökeller üzerine gelen killi kireçtaşları, soluk sarı ya da beyazımsı açık gri ayrışma renkli, düzgün ince-orta katmanlı ve yersel olarak düzlemsel paralel laminalıdır.
Belentepe üyesinin çak1l ve blok konsantrasyonu değişken moloz akması düzeyleri, gölsel istifin çamurtaşı egemen alt bölümüne yanal giriktir. (Şekil 6C). Reisdere volkanoklastiklerini oluşturan piroklastik ve epiklastik yoğunluk akıntılarından bazıları göle girmiş ve sualtında çökelmekte olan çamurlar üzerine yerleşerek yumuşak çökel deformasyonu oluşturmuşlardır. Bazı düzeylerin tabanlarında gözlenen sedimanter 'sokulumlar' (Şekil 6D), yük deformasyonları ve yumuşak çökel kopuntuları (Şekil 6E), yoğunluk akıntısı çökellerinin sualtı tortullaşmasıyla yaşıt yerleşimini yansıtır.

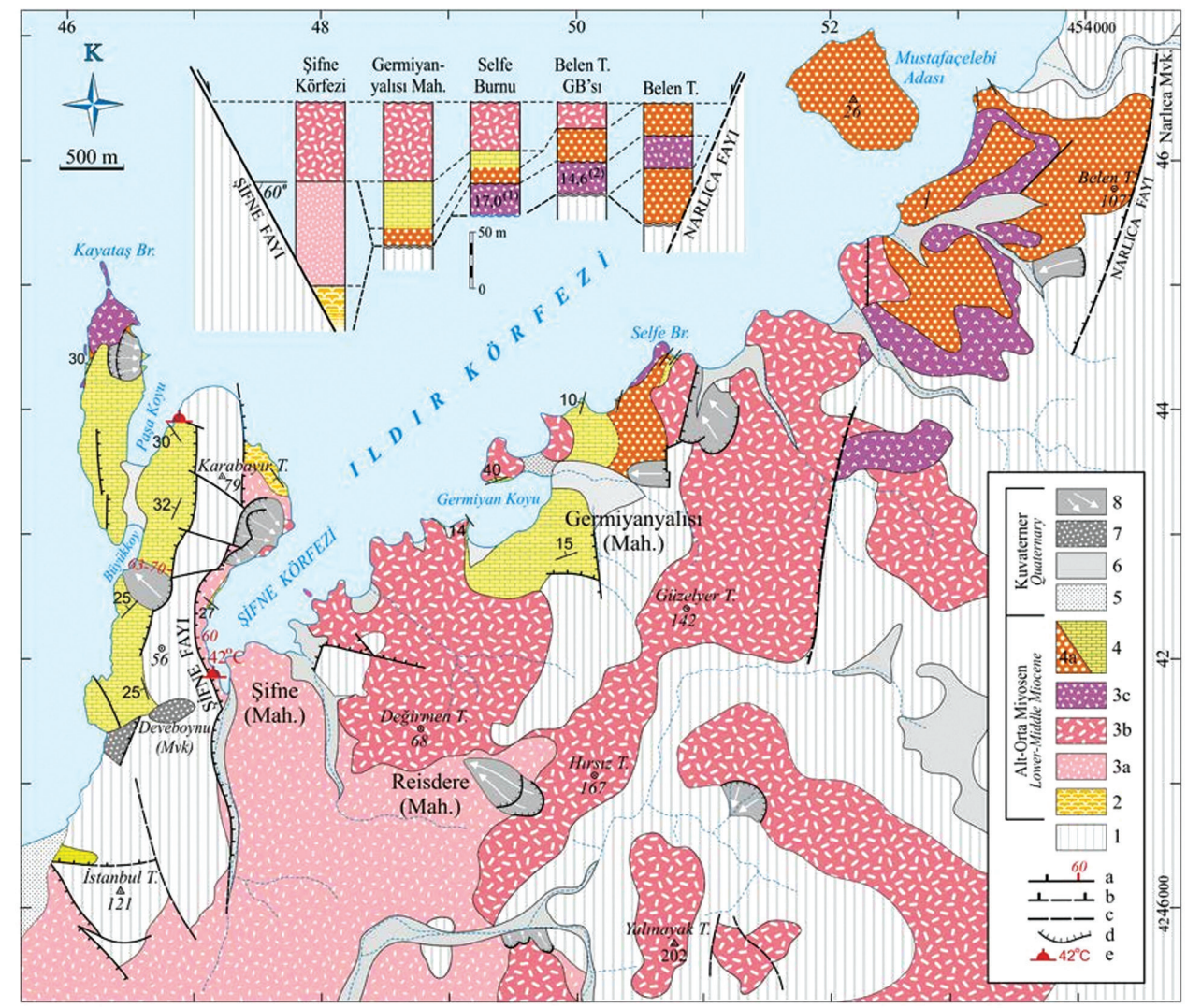

Şekil 5. Çalışma alanının jeoloji haritası. 1. Neojen öncesi temel, 2. Şifne Formasyonu, 3. Armağandağı Volkanitleri (a:Alaçatı Tüfü, b: Reisdere Volkanoklastikleri, c: Zeytineli Formasyonu), 4. Ildır Formasyonu (4a: Belentepe Üyesi), 5. Kumsal çökelleri, 6. Akarsu alüvyonu, 7. Yamaç molozu, 8. Heyelą kütlesi. a. Normal fay ve eğimi, b. Olası normal fay, c. Olası fay, d. Heyelan tacı, e. Sicak su kaynağı. (1) Borsi vd. (1972), (2) Bu çalışma.

Figure 5. Geological map of the study area 1. Pre-Neogene basement, 2. Şifne Formation, 3. Armağandağl Volcanics (a: Alaçatı Tuff, b: Reisdere Volcaniclastics, c: Zeytineli Formation), 4: Ildır Formation (a: Belentepe Member), 5. Beach deposits, 6. Fluvial deposits, 7. Slope debris, 8. Landslide debris. a. Normal fault and dipping degree, $b$. Probable normal fault, $c$. Probable fault, $d$. Landslide scarp, e. Hot spring. (1) Borsi et al. (1972), (2) This study. 

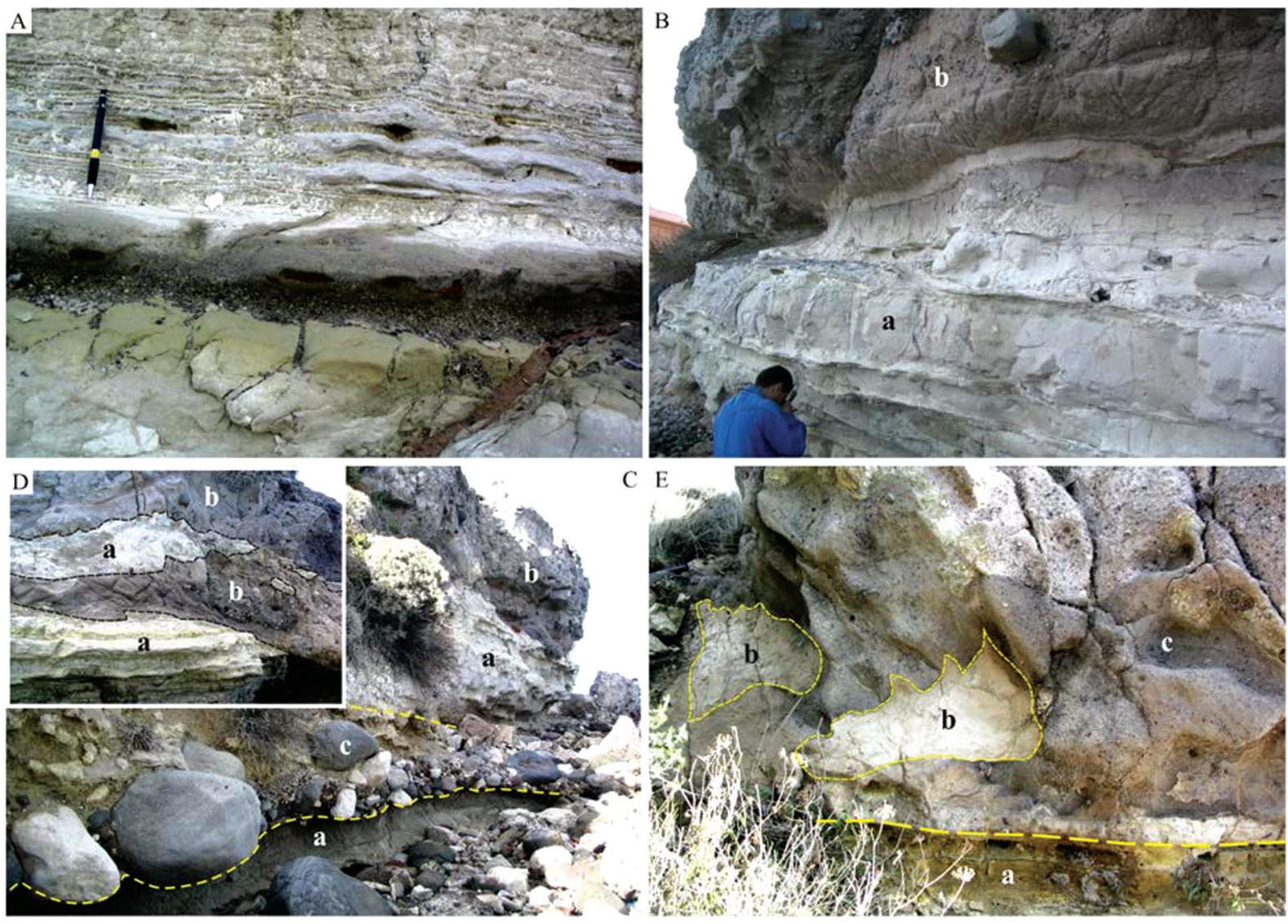

Şekil 6. Ildır formasyonu gölsel çökellerinin bazı sedimanter özelliklerini ve dokanak ilişkilerini yansıtan görüntüler: A) Alttaki kuruma çatlakları(?) üzerinde, doğru derecelenmiş kumtaşından itibaren gelişen olası dalga ripıllı çökeller. Kalem boyu 15 cm'dir. B) Sualtında çökelmiş çamurtaşları (a) ve üstleyen lahar düzeyi (b). C) Sualtında çökelmiş çamurtaşları içinde bloklu iri çakı1 aradüzeyleri bulunur; a) Çamurtaşı, b) Lahar, c) Blok-iri çakıl düzeyi; D) Sualtına giren lahar akıntısı ile üzerine yerleştiği sulu çamur arasında yumuşak çökel deformasyonu oluşmuştur; a) Çamurtaşı, b) Lahar. E) Göle giren piroklastik akma ünitesi içinde, göl tabanındaki sulu çamurdan aktarılmış iri parçalar yer alır; a) Sulu sediman kapanımları, b) Piroklastik akma düzeyi.

Figure 6. Photos showing some sedimentary features and contact relationships of the Ildir formation lacustrine deposits: A) Wave ripples on the graded sandstone covering the desiccation cracks(?). Pen is $15 \mathrm{~cm}$ long. B) Mudstone deposited in subaqueous conditions (a) and overlying lahar level (b). C) Block and cobble levels in subaqueous mudstone; a) Mudstone, b) Lahar, c) Block-cobble level; D) Soft sediment deformation between sludge and lahar flowed into the lake; a) Mudstone, b) Lahar. E) Large fragments plucked from sludge on the bottom of the lake in the pyroclastic flow deposits flowed into the lake; a) sludge enclaves, b) Pyroclastic flow deposit

Deveboynu Mevkii kuzeyinde, Güvercinlik Formasyonu'nun dolomitik kireçtaşlarına transgresif olarak yaslanan killikumlu kireçtaşları, diskordans yüzeyindeki karstik boşlukları ve çatlakları doldurur ve taban kesitinde, temelden türeme köşeli parçalar kapsar
(Şekil 7 A). Deveboynu Mevkii batısındaki sahilde yüzeyleyen kireçtaşları ise, birkaç metre kalınlığında, pembemsi soluk kahverenkli, boylanmamış kaba temel klastları içeren masif çamurtaşı düzeyi ile Güvercinlik formasyonu karbonatlarını örter (Şekil 7 B,C). 
Ildır formasyonunu yaşlandırabilecek biyokronolojik veri bulunmamaktadır. Belentepe üyesi içindeki mafik lav düzeyinin 14,6 My yaş1 ve birimin Çeşme Yarımadası batısındaki korelanı kabul edilen Çiftlik formasyonu'nda Besenecker (1973) tarafindan bulunan MN5 biyozonuna ait memeli fosilleri erken Orta Miyosen'i göstermektedir. Çalışma alanında üstten eksik gözlenen ve yüzeylediği kadarıyla erken Orta Miyosen yaşlı kabul edilen Ildır formasyonunun, geniş anlamda Orta Miyosen çökelimini temsil ettiği ileri sürülebilir.
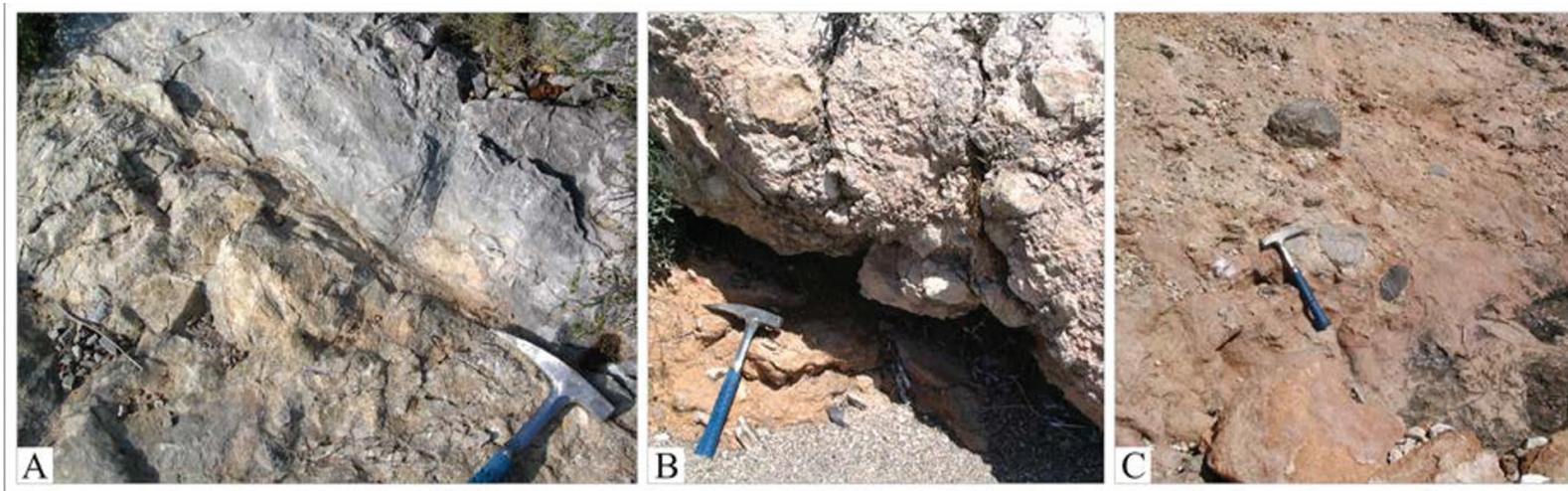

Şekil 7. Ildır gölsel istifinin transgresif aşmalı bölümleri, uyumsuz dokanaklarla temel kayalarına yaslanır. A) Gölsel kireçtaşları ile Güvercinlik formasyonu arasındaki uyumsuzluk. Gölsel kireçtaşları üzerinde duran çekicin ucu dokanağı gösterir (L16-b4; Deveboynu Mevkii kuzeyi). B,C) Gölsel kireçtaşlarının, kötü boylanmış çamurtaşları aracıllı̆̆ıla Güvercinlik Formasyonu’na yaslanan transgresif bölümleri. (L16-b4; Deveboynu Mevkii batıs1, sahil şeridi).

Figure 7. Transgressive onlapping parts of the Ildır lacustrine sequence overlie the basement rocks unconformably. A) The unconformity between lacustrine limestones and Güvercinlikformation. The sharp point of hammer on the lacustrine limestones shows the contact (L16-b4; north of Deveboynu site). B) Transgressive parts of the lacustrine limestone sequence overlying the Güvercinlik formation with poorly sorted mudstones (L16-b4; west of Deveboynu site, shoreline.).

\section{Belentepe $\ddot{U}$ yesi}

Ildır formasyonunun çökeldiği Orta Miyosen havzasının güney kenarındaki çökelimi yansıtan kaba çakıltaşı egemen istif, Göktaş (2010) tarafından tanımlanmıştır. Astbirimin adı, Germiyanyalısı Mahallesi'nin yaklaşı $4,5 \mathrm{~km}$ KKB'sındaki Belen Tepe'den alınmıştır (Şekil

5). Tortul istif içine sinsedimanter olarak yerleşen siyah renkli mafik lav düzeyi, Zeytineli formasyonu kapsamında incelenmiştir.

Başlıca yüzlekler, Germiyanyalısı Mahallesi ile Narlıca Mevkii arasında kalan bölgede yayılım gösterir (Şekil 5). Yoğun yerleşim nedeniyle istife yönelik değerlendirmeler, daha çok kıyı falezlerindeki gözlemlerle sınırlıdır. Alüviyal istif, lav düzeyinin araya girmesiyle bağıl olarak 'alt' ve 'üst' bölümlere ayrılır. Alt bölüm en çok 50 $\mathrm{m}$, üst bölüm ise $\sim 30 \mathrm{~m}$ kalınlıktadır.

Alt bölüm: Narlıca Mevkii’nin $1 \mathrm{~km}$ batısındaki yalıyarda, Dikendağı formasyonunun türbiditik çökelleri üzerinde aç1lı uyumsuzlukla yer aldığ 1 gözlenen alt bölüm istifinde, üç ayrı kayatürü topluluğu tanımlanmıştır. i) İstifin yaklaşık 5 metre kalınlığındaki alt kesiminde, alttan üste az gelişmiş tane boyu incelmesi gösteren örgütlenmemiş tortul breş fasiyesi yer alır (Şekil 8A,B). Katmanlanma belirsizdir. Kayatürünü oluşturan tane destekli-ara gereç dolgulu ya da matriks destekli kaba gerecin hemen tümü köşeliyarı köşelidir ve kaynaklanma alanındaki gri renkli Mesozoyik karbonat kayalarından türemiştir. 


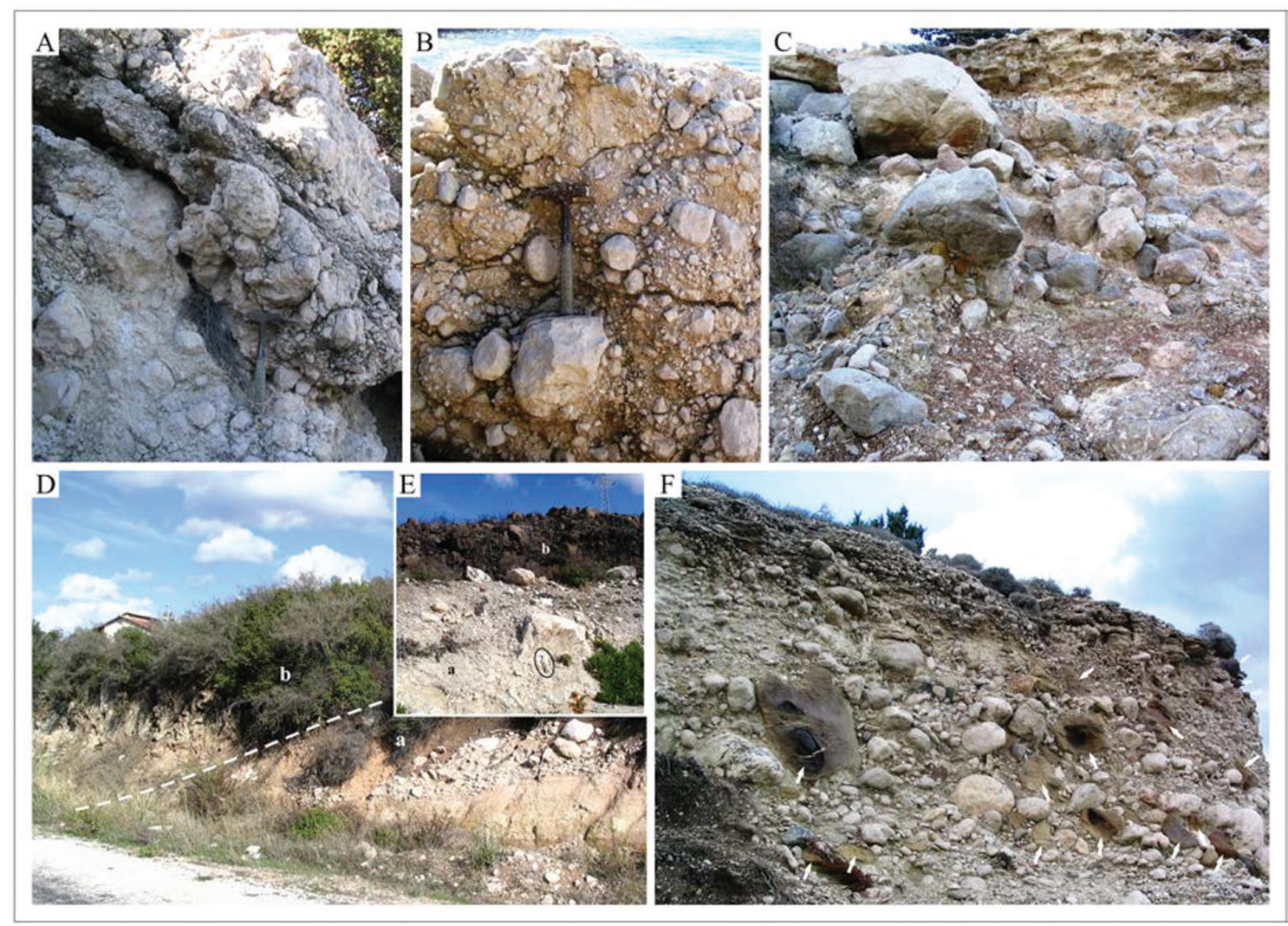

Şekil 8. Belentepe yelpaze deltası çökelleri. A) İstifin tabanında yer alan kolüviyal moloz akmalarından bir görünüm. B) Moloz akması fasiyesinde bloklu kaba çakııltaşı. C,D,E) İstifin suüstü bölümünde yer alan paleooksidasyona uğramış çamurtaşları içinde, bloklu moloz akması aradüzeyleri bulunur; a) Belentepe Üyesi, b) Zeytineli Formasyonu. F) Belentepe istifinin üst bölümüne egemen olan bloklu kaba çakıltaşları, Zeytineli Formasyonu'nun siyah lavlarından türeme kaba bileşenler (beyaz oklarla gösterilmiştir) kapsar.

Figure 8. Belentepe fan delta deposits. A) Coluvial debris flow deposits in the lowermost part of the succesion. B) Debris flow blocky coarse conglomerate facies. C,D,E) Blocky debris flow deposits in the subaerial weathered mudstones; a) Belentepe Member, b) Zeytineli Formation. F) Blocky coarse conglomerates including black lava fragments, which are dominated in the upper part of the succession.

Tabanda, 1 metreyi aşkın büyüklüklerde köşeliyarı köşeli bloklar bulunur. Gelişigüzel dağılmış kaba taneler arasındaki matriks, sarımsı açık gri ya da soluk pembe renkli, kötü boylanmış karbonatlı çamurtaşından oluşur. Çakıl konsantrasyonunun azaldığ1 ve boyutlarının küçüldüğü matriks destekli üst bölümlere çamurtaşları egemendir. ii) Tortul breş fasiyesi üzerine, yaklaşık $6 \mathrm{~m}$ kalınlığa ulaşan masif kiltaşı-çamurtaşı istifi gelir. İstife egemen olan kiltaşları, yeşilimsi gri ya da kızılkahverenkli, masif ve zayıf pekişmiştir. Silt ve ince kum içerikleri ile santimetrik kalınlıklardaki beyaz kaliş bantları olağandır. Kaba kum ve çakılcık içerikleri kapsayan çamurtaşları açık kahverenkli ve kötü boylanmıştır. iii) İnce kırıntılı çökel paketi üzerine, çok kalın masif düzeylerden oluşan örgütlenmemiş iri çakıltaşları gelir (Şekil 8C). Kalınlıkları 4 metreye kadar çıkan düzeylerin sinırları çoğunlukla belirsizdir. Alt ve üst sınırlar, düşey tane boyu farklılaşması ve çakı1/matriks oranındaki değişimle ya da kumlu çamurtaşı düzeylerinin araya girmesiyle az çok belirginleşir. Başlıca kayatürü bileşenleri, çok kökenli Mesozoyik karbonatlarından türemiştir. 
Doku matriks desteklidir. Matriks, çakılcık ve küçük çakıllar içeren kaba-çok kaba taneli kumdan oluşur. Çakıl-blok kapsamının matrikse oranı genellikle çok yüksektir. Çakıl ve bloklar çoğunlukla yarı yuvarlaktır. Boyutları ender olarak 3 metreyi aşan iri bloklar yaygındır. Köşeli-küt köşeli küçük çakıllardan oluşan ve kalınlıkları 15-35 cm arasında değişen çakıltaş1 mercekleri seyrektir. Bu mercekleri oluşturan tane destekli ve ara gereç içermeyen çakıllar iyi boylanmıştır. Belen Tepe batısında üste gelen lav dokanağına doğru, paleooksidasyonu yansitan açık kahverenkli ve kötü boylanmış kumtaşıkumlu çamurtaşı düzeyleri ortaya çıkar. Alt ve üst sınırları belirsiz olan metrik kalınlıklardaki masif düzeylerin içinde/arasında, tane destekli paketlenmiş yarı yuvarlak çakıllardan oluşan desimetrik kalınlıklarda çakıltaşı mercekleri bulunur (Şekil8D,E).

Üst Bölüm: Lav düzeyinin üzerindeki fan delta istifi, alt bölümde olduğu gibi, iri çakıl ve bloklardan oluşan birkaç metre kalınlığındaki masif çakıltaşı düzeyler ile simgelenir (Şekil $8 \mathrm{~F})$. Kaba gereç konsantrasyınu genel olarak çok yüksektir. Ara gereç destekli ve tane destekli-ara gereç dolgulu kesimler, aynı düzey içinde birlikte bulunur. Kaba taneli kumdan oluşan ara gereç, genellikle gri-yeşil renkli ve kötü boylanmıştır. Tane destekli ve ara gereç içermeyen köşeli küçük çakıllardan yapılı çakı1taşı mercekleri seyrektir. Üst bölümde, alt bölümden farklı olarak; i) alttaki mafik lav düzeyinden aktarılan altere çakıl ve bloklar (en çok $120 \mathrm{~cm}$ ) yaygındır, ii) çakıltaşı düzeylerinin arasında bulunan ve matriksi oluşturan çamurtaşları çoğunlukla yeşil renklidir, iii) blok boyutuna kadar kaba gereç içeren çamurtaşı aradüzeyleri bulunur, iv) litolojik köken ve boyutlara bağlı olmaksızın çakıl ve blokların yuvarlanma derecesi daha yüksek ve boyutları görece daha küçüktür.

Belentepe üyesinin stratigrafikpaleocoğrafik konumu ve egemen kayatürü bileşimi, Ildır formasyonunun çökeldiği Orta Miyosen havzasının güney kenarında gelişen gölsel fan delta tortullaşmasını yansıtır. İstifin büyük bölümünü oluşturan örgütlenmemiş iri çakıltaşı fasiyesi, fan delta çökeliminin moloz akmalarıyla belirlendiğini gösterir. Tortul istifin tabanında yer alan tortul breş fasiyesinin monolitik bileşimi ve kaba gerecin köşeli-küt köşeli şekilleri; havza açılımıyla birlikte yamaç önünde biriken döküntülerin, kolüviyal moloz akmalariyla (Blikra ve Nemec, 1998; Nemec vd., 1998; Nemec ve Kazanc1, 1999) taşınarak depolanmasını anlatır. İstifin tabanındaki tortul breş fasiyesinin tek kökenli bileşimine karşıllı, üst bölümlere egemen moloz akması düzeyleri ile seyrek kanal dolgularının çok kökenli bileşimi, yelpaze deltasının geri büyüme (retrogradation) sürecinde beslenme kanallarının geri kazımasıyla kazanılmıştır.

Alt bölümde gözlenen açı kahve paleooksidasyon renkleri su üstü (subaerial) çökeli mine, üst bölümlerdeki paleoredüksiyon renkleri ise su altı çökelimine özgüdür. Alt ve üst bölümlerde, seyrek olarak gözlenen tane destekli ve ara gereçten yoksun köşeli çakıl cepleri elenme loplarıdır (sieve lobes). İstifin özellikle en üst bölümlerinde gözlenen gölsel çökellere yanal giriklikler, su altı çökelimini destekler.

Belen Tepe çevresinde yüzeyleyen istifin alt bölümüne ait su üstü proksimal çökelleri, Dikendağ1 ve Gerence formasyonlarının simgelediği temel kayalarına açılı uyumsuzlukla yaslanır. Zeytineli formasyonunu temsil eden siyah renkli mafik lav, Belentepe üyesi içine sinsedimanter olarak yerleşmiş ve yayılım alanı içinde fan delta istifini ikiye bölmüştür. Üst bölüm çökelleri, yersel olarak Reisdere volkanoklastikleri tarafından örtülmüştür. İstifin yalnızca üst bölümü ile gölsel çamurtaşları arasında yanal giriklik gözlenmekle birlikte, Belentepe fan delta istifi ile gölsel istifin alttan üste yanal ilişkili olarak çökeldiği kabul edilmiştir. 
Ildır formasyonunun alt bölümünü oluşturan Belentepe üyesi, Karaburun Yarımadası'nın bireşimsel Neojen stratigrafisinde Orta Miyosen tortullaşmasının başlangıcını yansıtır ve bu konumuyla Karaburun çevresinde 'Hacıhüseyintepe üyesi' (Göktaş, 2014b), Urla havzasında 'Çamlı çakılltaşı' (Kaya, 1979) ve İzmir Dış Körfezi’ndeki adalar topluluğunda tanımlanan 'Beşiktepe formasyonu' (Göktaş, 2016) ile deneştirilebilir.

\section{Neojen Volkanizması}

Geç Erken Miyosen-erken Orta Miyosen döneminde Çeşme Yarımadası'nda etkinlik gösteren kalkalkalen volkanizmanın ürünleri Armağandağ incelenmiştir.

\section{Armağandağı Volkanitleri}

Armağandağ1 volkanitlerini oluşturan lavlar ve volkanoklastikler, ilk kez Türkecan vd. (1998) tarafindan aynı başlık altında topluca ele alınmıştır. Şifne formasyonu üzerinde felsik piroklastiklerle başlayan ve andezitik volkanitler ile devam eden Armağandağı volkanik kompleksinin hacimsel açıdan en büyük bölümünü volkanoklastik çökeller oluşturur. Volkanoklastik topluluğun asidik piroklastiklerden oluşan alt bölümü Alaçatı tüfü, ortaç volkanizma kökenliler Reisdere volkanoklastikleri olarak ayrılmış; ortaç volkanoklastiklere alttan üste yanal girik kabul edilen lav topluluğu ise Zeytineli formasyonu adıyla tanımlanmıştır (Şekil 4).

Armağandağ1 volkanizmasının Erken Miyosen içindeki başlangıç zamanı bilinmemekle birlikte, Alaçatı tüfünün simgelediği erken dönem piroklastiklerinin Şifne formasyonunun algli kireçtaşları üzerine sinsedimanter olarak yerleştiği açıkça gözlenmektedir.

\section{Alaçatı Tüfü}

Çalışma alanındaki kayastratigrafik konumuna dayanılarak, Armağandağı kalkalkali volkanizmasının asidik karakterli erken dönemini yansıttığı kabul edilen Alaçatı tüfü, çok katlı ignimbirit üniteleri ile simgelenir. Çeşme Yarımadası'ndaki tüflerin varlığına ilk kez Kalafatçıoğlu (1961) değinmiştir. Alaçatı tüfünün, kalkalkali dasit-riyolit bileşim aralığında piroklastiklerden oluştuğu Kaçmaz ve Köktürk (2004) tarafindan belirlenmiştir. Birimin ilk kez bu çalışmada kullanılan adı, Çeşme ilçesine bağlı Alaçatı Mahallesi’nden alınmıştır.

Beyazımsı açık gri renkli felsik piroklastik istif, zayıf kaynaklı ignimbiritlerle simgelenir. Kül döküntüsü (ash fall) tüf aradüzeyleri seyrektir. İgnimbiritlerin yaygın olarak kapsadığ 1 rastlantısal (accidental) kaba volkanik bileşenler türdeş değildir; koyu gri ve siyah renkli andezitlerin çoğunlukta olduğu lav parçaları ile simgelenir. Türdeş litiklere çalışma alanında rastlanmamıştır. Şifne formasyonunun algli kireçtaşlarından aktarılmış parçalar, özellikle alt bölümlerdeki ignimbirit ünitelerinde yaygın olarak gözlenir (Şekil 9A). Kumdan iri blok boyutlarına kadar düzensiz tane boyu değişimi gösteren andezitik litiklerin büyüklüğü ve kaba külden yapılı matrikse oran1, Armağan Dağı'na yaklaştıkça artar.

Genelleştirilmiş stratigrafide Alaçatı tüfü, Şifne formasyonunun algli kireçtaşlarını keskin dokanaklarla örter. İgnimbiritler içinde rastlanan yumuşak çökel deformasyonuna uğramış kireçtaşı kopuntuları, volkanik etkinliğin sinsedimanter gelişimini yansıtır. Birim, Reisdere volkanoklastikleri tarafindan örtülür. İgnimbiritlerin yaygın olarak içerdiği andezitik kaba litikler, ortaç volkanizmanın felsik ignimbiritlerin yerleşiminden önce başlamış olabileceğini düşündürür. 
Alaçatı GD'sunda ignimbiritleri örten andezitlerden 18.2 My K/Ar yaşı alınmıştır (Borsi vd., 1972). Bu dolaylı veriye dayanılarak, Alaçatı tüfünün geniş anlamda geç Erken Miyosen yaşı olduğu ileri sürülebilir.

Türkecan vd. (1998), Çeşme Yarımadası'ndaki asidik tüfleri Foça tüfünün (Kaya, 1979) uzantısı olarak yorumlamışlardır. Bu çalışmada ise, andezitik kaba litikler içeren felsik piroklastiklerin Armağan Dağı çıkış merkezinden türedikleri ve kalkalkali volkanizmanın erken döneminde yerleştikleri kabul edilmiştir. Piroklastik akıntıların algli kireçtaşı platformunu kapladığı alanlarda Şifne formasyonu çökelimi sona ermiş ve Erken Miyosen havzası, Ovacık formasyonunun (Göktaş, 2010) simgelediği gölsel çökelimin yeniden başlamasına kadar karasallaşmıştır.

\section{Reisdere Volkanoklastikleri}

Reisdere volkanoklastikleri (Göktaş, 2010), daha çok andezitik piroklastiklerden ve epiklastik çökellerden oluşur.

Volkanik çamur/moloz akması (lahar) fasiyesindeki epiklastik çökeller, daha önce yerleşmiş andezitik piroklastiklerin ve lahar düzeylerinin yeniden işlenmesiyle çökelmiş bloklu çakıltaşlarıyla simgelenir. Matriksi kaba taneli volkanik kumdan oluşan örgütlenmemiş kütle akması düzeyleri metrik kalınlıklardadır. Kendi aralarında ya da piroklastik akma düzeyleri ile birlikte çok katlı tortullaşma birimleri oluştururlar. Başlıca kayatürü bileşenleri, farklı renk ve dokusal özelliklerdeki andezitlerden türemiştir. Tane/ matriks oranı ve/veya tane büyüklüklerinin düşey değişimiyle ayırtlanan katmanlanma çoğunlukla az belirgindir (Şekil 9B).

Bloklu kül akışı (block and ash flow) ve ignimbirit gibi yoğunluk akıntısı fasiyesleri ile simgelenen andezitik piroklastikler, metrik kalınlıklarda ve masif düzeylerden oluşur (Şekil). 9C). Lav parçaları, santimetrik-desimetrik büyüklüklerde ve genellikle yarı köşelidir. Matriks içinde düzensiz dağılım gösteren lav parçalarının yanal ve düşey yönlerdeki konsantrasyonu değişkendir (Şekil 9D). Kaba küllapilli boyutlarındaki jüvenil bileşenlerden yapılı matriks, olağan olarak kötü boylanmıştır.

Reisdere volkanoklastikleri, üzerledikleri Alaçatı tüfünü yanal yönde aşarak Tersiyer öncesi temel kayalarına yaslanır. Çalışma alanındaki üst dokanaklar genellikle Kuvaterner aşınımıyla belirlenmiştir. Ildır formasyonu çökellerini örten birimin en genç düzeyleri üzerinde, Holosen çökelleri ve yersel heyelan molozları dışında kayatürü kalıntısı bulunmaz.

\section{Zeytineli Formasyonu}

Zeytineli formasyonu (Göktaş, 2010), Armağandağı volkanitleri kapsamındaki kalkalkali lav topluluğunu kapsar. Önceki çalışmalarda kimyasal özellikleri incelenen lavların çoğunlukla andezit ve daha az oranda dasit bileşimli oldukları bildirilmiştir (Innocenti ve Mazzuoli, 1972; Türkecan vd., 1998; Helvacı vd., 2009; Göktaş, 2010). Çalışma alanında Zeytineli formasyonunu temsil eden siyah renkli mafik lavlar, Armağandağı volkanitleri içindeki ortaç lav topluluğunun hacimsel olarak en büyük bölümünü oluşturur. Birimin başlıca yüzlekleri, Ildır Körfezi'nin güney kıyısındadır (Şekil 10A). Siyahımsı koyu gri renkli olan lavlar bloksu ayrışmalı, genellikle devitrifiye ve çok sert, nadiren akma foliyasyonludur.

Belen Tepe çevresinde ayırtlanan lav akıntısı, genelleştirilmiş stratigrafide Belentepe üyesi içinde yer alır. Tip lokalite çevresinde, alüviyal istifi bağıl olarak alt ve üst bölümlere ayırır ya da alt bölümün proksimal çökellerini 


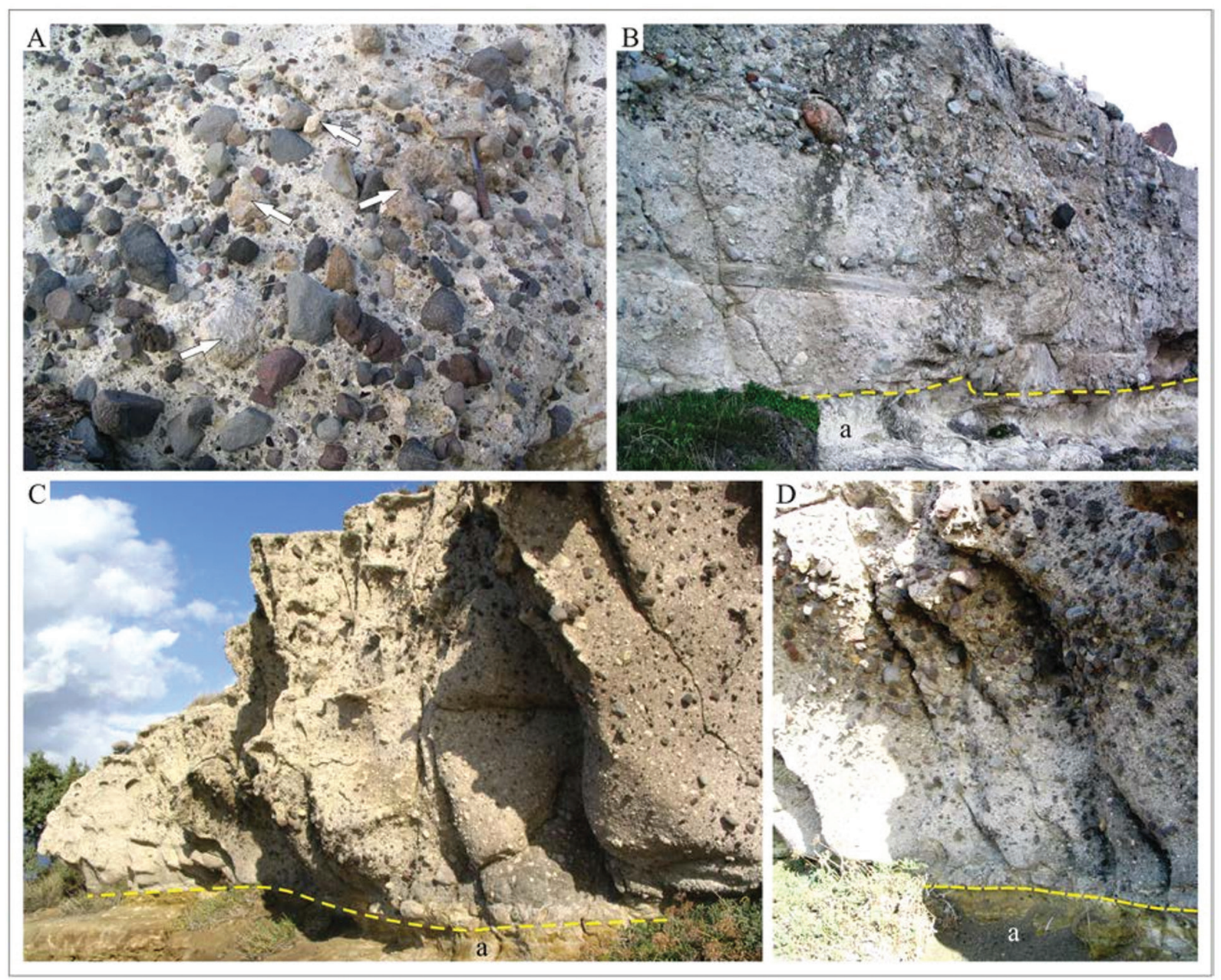

Şekil 9. Armağandağı Volkanitleri kapsamındaki volkaniklastiklerden görüntüler. A) Alaçatı Tüfü’nü oluşturan ignimbiritler, özellikle proksimal kesimlerinde artı̧̧ gösteren andezitik litikler yönünden oldukça zengindir. Beyaz oklar, Şifne Formasyonu'ndan aktarılmış algli kireçtaşı parçalarını gösterir. B) Reisdere Volkaniklastikleri kapsamındaki lahar düzeylerinden biri. a) Ildır Formasyonu'nun gölsel çamurtaşları C, D) Aynı stratigrafik pozisyondaki piroklastik akma düzeyleri. a) Ildır Formasyonu'nun gölsel çamurtaşları

Figure 9. Some photos from volcaniclastics in Armağandă̆ı Volcanics. A) Ignimbrites of Alaçatı Tuff have abundant andesitic lithic clasts in their proximal part. White arrows show algae limestone fragments derived from the Şifne Formation. B) A lahar level in Reisdere Volcaniclastics. a) Lacustrine mudstones of Ildir Fm. C,D) Pyroclastic flow levels in the same stratigraphic position. a) Lacustrine mudstones of Ildir Fm. 


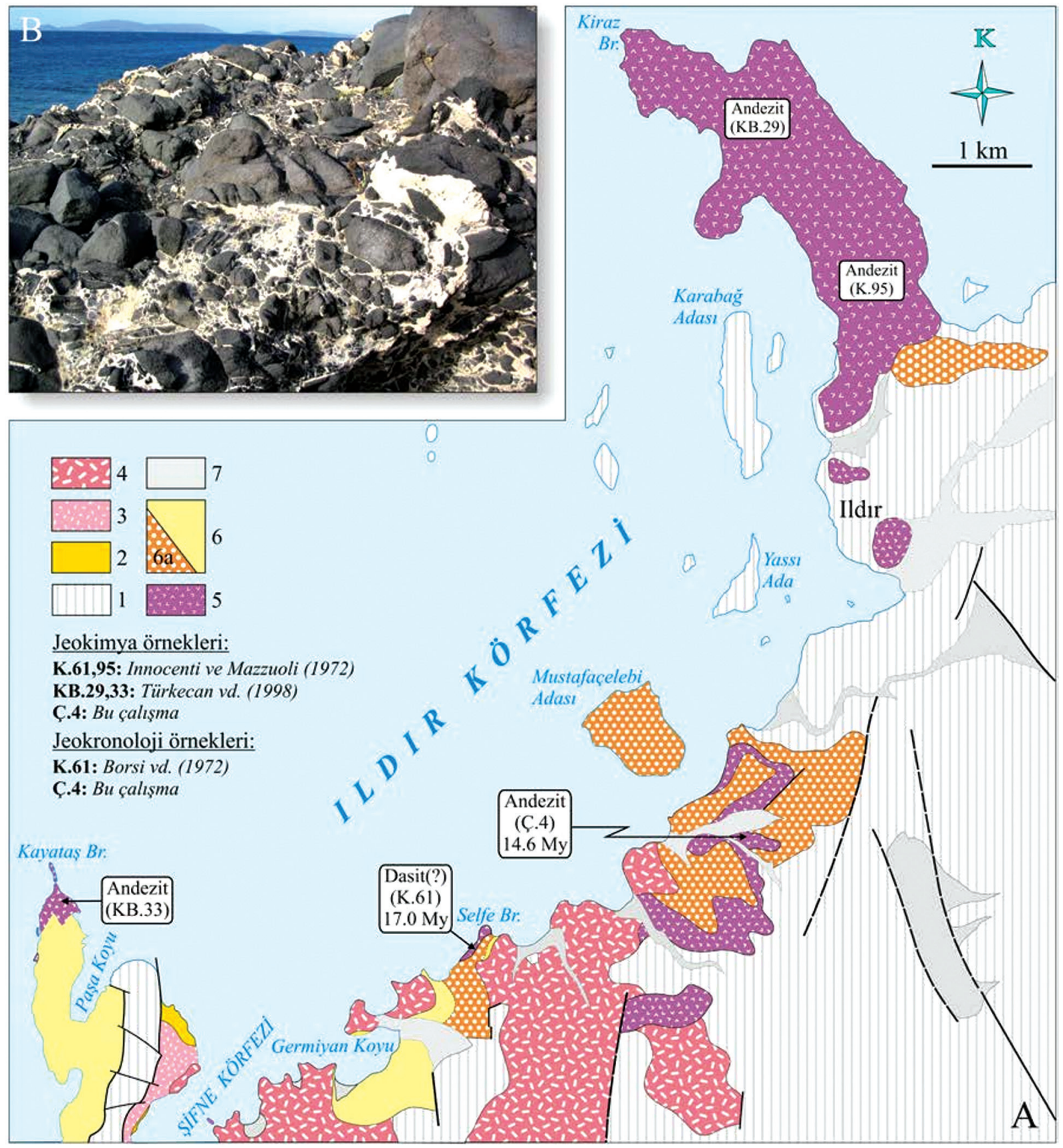

Şekil 10. A) Zeytineli Formasyonu'nun inceleme alanındaki dağılımı. 1. Neojen öncesi temel kayaları, 2. Şifne Formasyonu, 3. Alaçatı Tüfü, 4. Reisdere Volkaniklastikleri, 5. Zeytineli Formasyonu, 6. Ildır Formasyonu (6a: Belentepe Üyesi) 7. Alüvyon. B) Belentepe Üyesi'nin sualtı çökelleri olarak yorumlanan çakıllı çamurtaşlarına tortullaşmayla eşzamanlı olarak sokulan Zeytineli Formasyonu lavında peperitleşme (Kayataş Burnu).

Figure 10. A) Spatial distribution of Zeytineli Formation in the study area. 1. Pre-Neogene basement rocks, 2. Şifne Formation, 3. Alaçatı Tuff, 4. Reisdere Volcaniclastics, 5. Zeytineli Formation, 6. Ildır Formation (6a: Belentepe Member), 7. Alluvium. B) Pepperitization in lavas of Zeytineliformation, which synsedimentary intruded into the pebbly mudstones interpreted as subaqueous deposits of Belentepe Member. 
aşarak Gerence formasyonu karbonatlarına yaslanır. Kayataş Burnu'nda gözlenen lav düzeyi ise, Belentepe fan delta istifinin sualtı uzantıları olabilecek yeşil renkli çakıltaşı-çakıllı çamurtaşı topluluğu içine 'sokulmuş' ve dokanak peperitleşmiştir (Şekil 10B). Bu lokalitedeki masif çamurtaşları içinde gözlenen ve Mesozoyik karbonatlar ile daha az oranda siyah andezit lavından türemiş çakıllar, havza kenarının yakın olduğunu düşündürür.

$\begin{array}{lrr}\begin{array}{l}\text { Önceki } \\ \text { çalışmalarda, } \\ \text { volkanoklastiklerini } \\ \text { andezitlerden, }\end{array} & \begin{array}{l}\text { Reisdere } \\ \text { kerleşen }\end{array}\end{array}$

18.2 My (Borsi vd., 1972) ve 17.3 My (Helvacı vd., 2009) yaşları alınmıştır. Zeytineli formasyonundan bu çalışmada alınan 14.6 My yaşı, Armağandağı volkanik kompleksindeki lav çıkışlarının en azından erken Orta Miyosen'e kadar devam ettiğini gösterir.

\section{PETROGRAFI}

Çalışma alanında Zeytineli formasyonunu simgeleyen hipokristalin-porfirik dokulu lav örneklerinin fenokristal kapsamı, plajiyoklaz, piroksen ve amfibolden oluşur. Plajiyoklazlar çoğunlukla polisentetik ikizlenmeli ve yer yer zonludur. Nadiren elek dokusu, sinosis dokusu ve glomeroporfirik doku özellikleri gösterir. Klinopiroksen kristalleri soluk kahverenkli, yer yer ikizlenmeli ve glomeroporfirik dokuludur. Yarı özşekilli-özşekilsiz amfiboller kahverenkli ve yer yer ikizlenmelidir. Plajiyoklaz ve opaklaşmış biyotit mikrolitleri, volkan cam1, kristalitler ve opak minerallerden oluşan hamur, bazı örneklerde belirgin akma dokuludur.

\section{ANA ELEMENT OKSİT JEOKIMYASI}

Zeytineli formasyonunu temsilen alınan Ç.4 örneğinin ana element oksit analizi, MTA Maden
Analizlerive Teknolojisi Dairesi laboratuvarlarında yapılmıştır. $75 \mu$ altında ögütülen ve $1050 \mathrm{C}$ 'de kurutulan örnekten 3 gr alınarak 0,9 gr selüloz bağlayıcı ile karıştırılmış ve 15 dakika öğütülerek homojen dağılım sağlanmıştır. Değirmenden çıktıktan sonra 40 ton basınçla preslenen örneğin Panalytical marka, Axios model XRF cihazı ile analizi yapılmış ve sonuçlar IQ+ programında değerlendirilmiştir.

$\mathrm{Bu}$ çalışmada ve önceki çalışmalarda (Innocenti ve Mazzuoli, 1972; Türkecan vd.,1998) Zeytineli formasyonundan alınan lav örneklerinin lokasyonları Şekil 10'da, ana element oksit içerikleri Çizelge 1'de verilmiştir. Innocenti ve Mazzuoli (1972)'nin bir, Türkecan vd. (1998)'nin iki ve bu çalışmada alınan bir örneğin ana element oksit bileşimleri (Çizelge 1) Le Bas vd. (1986)'nin Toplam Alkali (Na2O+K2O) Silis ( $\mathrm{SiO} 2)$ diyagramına yansıtılmış; subalkali bölümde yer alan örneklerin kalkalkali karakterli olduğu ve 'andezit' alanında toplandığı gösterilmiştir. (Şekil 10A). K.61 örneğinin (Innocenti ve Mazzuoli, 1972) yüksek silis içeriği diğer örneklere göre sapma gösterir ve olasılıkla silis kapsamındaki ikincil artış nedeniyle 'dasit' alanına düşer. Diğer örneklerin silis içerikleri ağırlıklı olarak \%59,90$\% 60,50$ arasında değişirken, K.61 örneğinde \%66.17'ye çıkar. Bu nedenle K.61 örneği göz ardı edildiğinde, çalışma alanında Zeytineli formasyonunu simgeleyen lavlar 'andezit' olarak adlandırılabilir Irvine ve Baragar (1971)'ın AFM diyagramına göre kalkalkalen karakterli olan tüm örnekler (Şekil 10B), Le Maitre vd. (2002)'nin K2O'ya karşı SiO2 diyagramında 'yüksek potasyumlu andezit' alanında toplanır (Şekil 10C). Çalışma alanında değerlendirilen lav örnekleri, Armağandağı volkanitlerini simgeleyen yüksek potasyumlu kalkalkali andezit seri (Innocenti ve Mazzuoli, 1972; Helvacı vd., 2009) içinde yer alır. 


\begin{tabular}{|c|c|c|c|c|c|c|c|c|c|c|c|c|c|}
\hline Örnek & $\mathrm{SiO}_{2}$ & $\mathrm{TiO}_{2}$ & $\mathrm{Al}_{2} \mathrm{O}$ & $\mathrm{Fe}_{2} \mathrm{O}_{3}$ & $\mathrm{MnO}$ & $\mathrm{MgO}$ & $\mathrm{CaO}$ & $\mathrm{Na}_{2} \mathrm{O}$ & $\mathrm{K}_{2} \mathrm{O}$ & $\mathrm{P}_{2} \mathrm{O}_{5}$ & $\mathrm{SrO}$ & $\mathrm{BaO}$ & $\mathrm{LOI}$ \\
\hline $\mathrm{C} .4$ & 59.90 & 0.60 & 16.70 & 6.30 & 0.10 & 2.80 & 5.90 & 3.40 & 2.40 & 0.20 & 0.07 & 0.09 & 1.40 \\
\hline $\mathrm{K} .61$ & 66.17 & 0.50 & 15.64 & 3.64 & 0.06 & 1.37 & 4.05 & 3.53 & 3.35 & 0.15 & -- & -- & 1.40 \\
\hline $\mathrm{K} .95$ & 61.07 & 0.63 & 16.27 & 5.22 & 0.11 & 3.36 & 5.74 & 3.38 & 2.99 & 0.21 & -- & -- & 0.94 \\
\hline $\mathrm{KB} .29$ & 59.80 & 0.60 & 15.90 & 5.70 & 0.20 & 3.30 & 5.50 & 3.10 & 3.10 & 0.20 & -- & -- & 1.85 \\
\hline KB.33 & 60.50 & 0.60 & 17.20 & 5.50 & 0.10 & 2.60 & 5.10 & 3.20 & 2.60 & 0.20 & -- & -- & 1.03 \\
\hline
\end{tabular}

Çizelge 1. Zeytineli formasyonuna ait örneklerin ana element oksit analiz sonuçları.

Table 1. Major element oxide analize results of the samples taken from Zeytineli formation
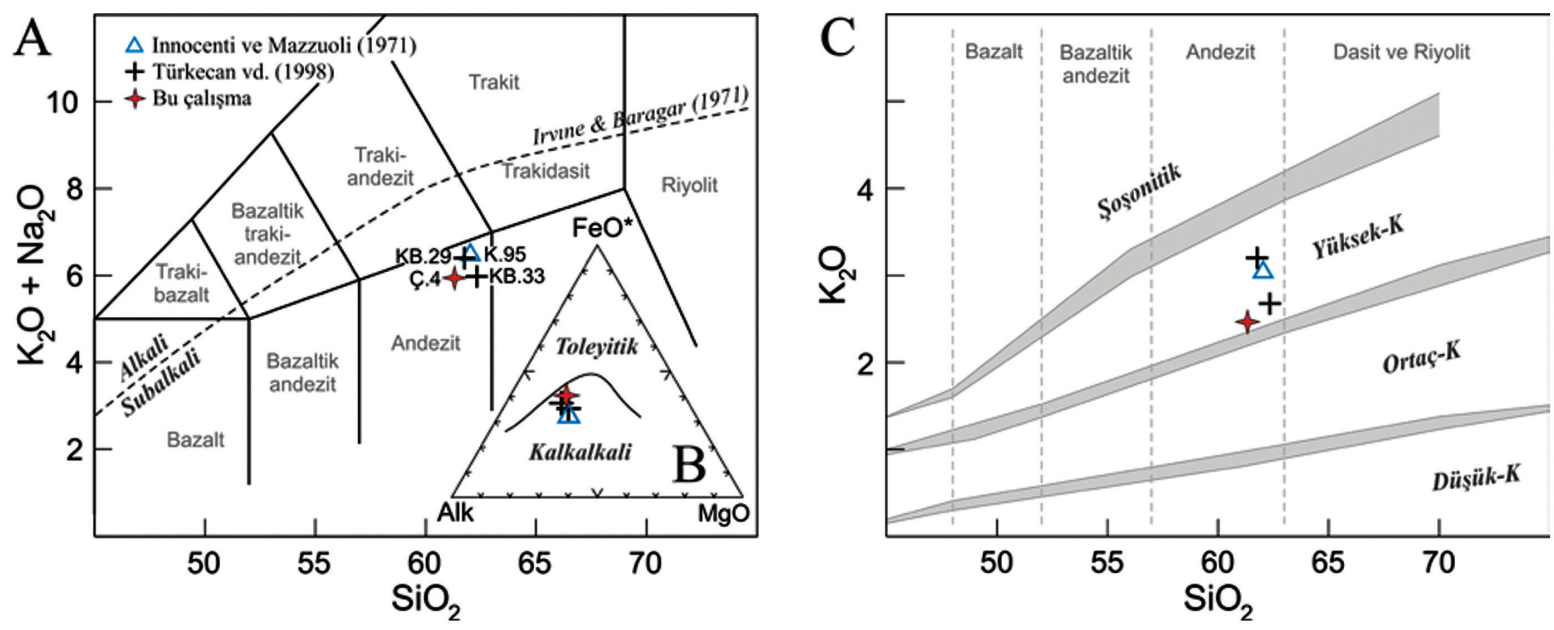

Şekil 11. Zeytineli Formasyonu lavlarının sınıflandırması. A) Örneklerin Toplam Alkali ( $\left.\mathrm{K}_{2} \mathrm{O}+\mathrm{SiO} 2\right)-\mathrm{Silis}(\mathrm{SiO} 2)$ diyagramı (Le Bas vd., 1986). Alkali-Subalkali ayrım çizgisi Irvine ve Baragar (1971)'a göredir. B) Subalkali örneklerin AFM diyagramı (Irvine ve Baragar, 1971). C) K2O'ya karşı SiO2 diyagramı (Le Maitre vd., 2002).

Figure 11. Classification of lavas of Zeytineli Formation. A) Total Alkaline (K2O+SiO2)-Silica (SiO2) diagramme (Le Bas et al., 1986). The Alkaline-Subalkaline line was drawn based on Irvine and Baragar (1971). B) AFM diagramme of subalkaline samples (Irvine and Baragar, 1971) C) $\mathrm{SiO} 2$ vs K2O diagramme (Le Maitre et al., 2002).

\section{K/Ar JEOKRONOLOJISI}

Zeytineli formasyonunun siyah renkli lavlarını temsil eden Ç.4 kodlu andezit örneğinin $\mathrm{K} / \mathrm{Ar}$ analizi Tübingen Üniversitesi'nde (Almanya)

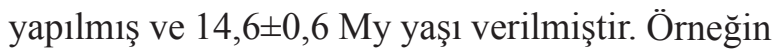
lokasyonu Şekil 10'da, radyometrik analiz sonucu
Çizelge 2'de gösterilmiştir. Yüzey verilerine göre,

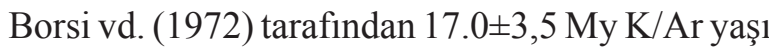
alınan Selfe Burnu'ndaki dasit(?) ile bu çalışmada yaşlandırılan andezit düzeyi aynı litostratigrafik konumdadır (Şekil 10). 


\begin{tabular}{|c|c|c|c|c|c|}
\hline Örnek & Materyal & $\mathbf{K}(\mathbf{w t} \%)$ & $\begin{array}{c}{ }^{40} \mathbf{A r} \text { rad } \\
\left({ }^{c} \mathbf{c S T P} / \mathrm{gr}\right)\end{array}$ & ${ }^{40} \mathbf{A r}$ rad $(\%)$ & Yaş (My) \\
\hline Ç.4 & Tüm kayaç & 1.210 & $6.892 \times 10^{-7}$ & 59.0 & $14.6 \pm 0.6$ \\
\hline
\end{tabular}

Çizelge 2- Zeytineli formasyonundan alınan lav örneğine ait radyometrik analiz verileri.

Table 2: $\quad$ Radiometric analize data of a lava sample taken from Zeytineli formation.

\section{SONUÇLAR}

$\mathrm{Bu}$ çalışmada, Ildır Körfezi güneyinde yayılımı bulunan karasal Neojen çökelleri ile volkanitlerinin yanal-düşey dağılımları ve ilişkileri araştırılmış; önerilen stratigrafi düzeni içinde sinıflandırılarak litolojik özellikleri tanımlanan kaya birimleri 1:25.000 ölçekte haritalanmıştır. Çeşme Yarımadası'nda, Neojen öncesi temel kayaları üzerinde açılı uyumsuzlukla başlayan Orta Miyosen tortullaşması ve yanal ilişkili kalkalkali andezitik volkanizma, bu çalışmayla ilk kez tanıtılmıştır.

Karaburun Yarımadası'nın bireşimsel Neojen stratigrafisinde Erken Miyosen gölsel tortullaşmasına karşılık gelen ve alt dokanağ1 yüzeylemeyen Şifne formasyonunun, istifin yüzeyleyen en üst bölümündeki tatlı su algli kireçtaşlarıyla simgelendiği ve Alaçatı tüfü kapsamındaki felsik ignimbiritlerin kireçtaş1 platformu üzerine sinsedimanter yerleşimiyle gölsel çökelimin sona erdiği belirlenmiştir.

Armağandağ1 volkanitleri, alttan üste asidik piroklastiklerden oluşan Alaçatı tüfü, baskın olarak andezitik volkanizma türevi Reisdere volkanoklastikleri ve siyah renkli andezit lavlarının simgelediği Zeytineli formasyonuna ayrılmıştır.

Geniş anlamda Orta Miyosen, dar anlamda erken Orta Miyosen yaşlı havza dolgularından oluşan Ildır formasyonu, Armağandağı volkanitlerinin uzantıları olan arakatkılar kapsar. Neojen öncesi temel kayaları üzerinde açılı uyumsuzlukla başlayan Ildır formasyonu tortullaşmasının, Reisdere volkanoklastiklerinin yerleşimiyle yersel olarak kesintiye uğradığ değerlendirilmiştir. Havza kenarı çökelimini temsil eden Belentepe istifine kaba taneli kütle akması çökellerinin egemen olduğu; yeşil çamurtaşlarıyla başlayan gölsel çökelimin kireçtaşlarıyla devam ettiği belirlenmiştir. Belentepe üyesinden türemiş kütle akıntılarının, gölsel istifinin çamurtaşı egemen alt bölümüne sokulduğu saptanmış; fan delta ve gölsel istiflerin alttan üste yanal ilişkili olarak çökeldiği kabul edilmiştir.

Çalışma alanında Zeytineli formasyonunu temsil eden ve Ildır formasyonu içine çökelimle eşzamanlı yerleştiği anlaşılan siyah renkli lav düzeyinin, ana element oksit bileşimine göre kalkalkali karakterli ve yüksek potasyumlu

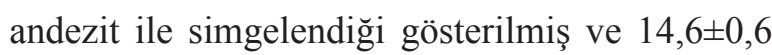
My K/Ar yaşlı olduğu saptanmıştır. Belentepe istifi içine yerleşen lav akıntısının, yanal ilişkiyle çökelmekte olan gölsel çamurtaşlarıyla peperitik dokanak oluşturduğu gösterilmiştir. Reisdere volkanoklastik akıntılarının, üzerine yerleştikleri gölsel çökellerde yumuşak çökel deformasyonlarına neden oldukları belirlenmiştir. $\mathrm{Bu}$ veriler, Ildır formasyonu tortullaşmasıyla Armağandağı volkanizmasının erken Orta Miyosen boyunca yanal ilişkili gelişim gösterdiğini anlatır.

\section{TARTIŞMA}

Armağandağı volkanizmasının erken döneminde yerleştiği kabul edilen Alaçatı tüfünün felsik ignimbiritleri içinde kaba andezit klastları ile simgelenen rastlantısal litiklerin yaygın olarak 
bulunması, asidik volkanizma öncesinde başlayan ortaç volkanizmayı düşündürür.

Şifne formasyonu çökelimini sonlandıran felsik ignimbiritlerin yayılım alanı ve yerleşim süresi içinde kesintiye uğradığı anlaşılan geç Erken Miyosen gölsel tortullaşmasının, Çeşme Yarımadası batısında Ovacik formasyonuyla devam ettiği bildirilmiştir (Göktaş, 2010). Ovacık gölsel transgresyonu, Ildır Körfezi güneyindeki bölgeye ulaşmamış olmalıdır. Karaburun Yarımadası kuzeyinde olduğu gibi, ignimbiritlerin yayılım alanı dışında kalan bölgelerdeki geç Erken Miyosen gölsel tortullaşması (Haseki formasyonu: Göktaş,2014a) ortamsal sürekliliğini korumuştur.

Ovacık formasyonu üzerine uyumlu gelen Çiftlik formasyonu (Göktaş, 2010), gölsel çökelimin Orta Miyosen' de devam ettiğini yansıtır. Çiftlik formasyonu ile bu çalışmada tanımlanan Ildır formasyonunun eşitlenebileceği önerilmiştir (Şekil 2). Aralarında yanal bağıntı gözlenmeyen iki gölsel istifin korelasyonu dolaylı kronostratigrafi verilerine ve litofasiyes benzerliklerine dayanmaktadır. Çiftlik formasyonunun alt bölümünü oluşturan Azmakdere istifinde (Göktaş, 2010) ve onun Sakız Adası'ndaki eşleniğinde (Keramaria ünitesi: Besenecker, 1973) saptanan memeli faunasının 15.5 My'a tarihlenen ortalama yaşı (Koufos, 2006) ile Ildır formasyonu içindeki sinsedimanter andezit düzeyinin jeokronolojisi, her iki birimin yaklaşık olarak aynı zamanda çökeldiğini düşündürür. Çiftlik formasyonunun tabanında,(Ildır formasyonundaki Belentepe üyesi gibi) Orta Miyosen havza açılımını yansıtan alüviyal çökeller bulunmamaktadır. Geç Erken Miyosen yaşlı Ovacık ve Orta Miyosen yaşlı Çiftlik gölsel istifleri arasındaki uyumlu ilişkiye karşılık, havzanın ani derinleşmesini yansıtan litofasiyes değişimi belirgindir. Ildır formasyonu, Orta Miyosen başlarında tektonik olarak derinleşen ve Çeşme Yarımadası'nın KD'suna doğru genişleyen Erken Miyosen havzasının, Ildır Körfezi çevresinde açılan kesiminde çökelmiş olmalıdır. Yarımadanın batısında ise, Erken Miyosen'den kalıtsal havza içinde kesintisiz devam eden gölsel ortam koşullarında Çiftlik formasyonu eşzamanlı olarak çökelmiştir.

Reisdere volkanoklastiklerini oluşturan piroklastik-epiklastik yoğunluk akıntısı düzeyleri ile Ildır gölsel istifi arasında yanal giriklik saptanmış ve volkanoklastiklerin yayılım alanlarıyla sınırlı olarak kesintiye uğrayan Orta Miyosen gölsel tortullaşmasının kireçtaşlarıyla devam ettiği önerilmiştir.

Zeytineli formasyonundan bu çalışmada alınan 14,6 My yaşı, Armağan Dağı volkanik kompleksindeki kalkalkali ortaç volkanizmanın erken Orta Miyosen'de devam ettiğini belgelemektedir. Bu veriye dayanılarak, Karaburun Yarımadası ve Sakı Adası'nda kalkalkali volkanizmanın sönümlenmesiyle eşzamanlı olarak, Foça Çöküntüsü’nde (Kaya, 1979) alkali volkanizmanın başladığı ileri sürülebilir (Borsi vd., 1972; Bellon vd., 1979; Altunkaynak vd., 2010; Göktaş, 2011, 2016; Karacık vd., 2013).

\section{KATKI BELIRTME}

Bu makale, 'Çeşme, Urla, Cumaovası, KemalpaşaTorbalı Çöküntülerindeki Neojen ve Kuvaterner Havzalarının Stratigrafisi ve Paleocoğrafik Evrimi' (2007-30-14-01.f) adl1 MTA projesi kapsamında, Çeşme Yarımadası'nda yürütülen çalışmaların bir bölümünü kapsar. Jeo. Yük. Müh. Murat Yükünç arazi çalışmalarına yardımcı olmuştur. Metin taslağının hazırlanmasına çok yönlü katkılarından dolayı Dr. H. Yavuz Hakyemez’e teşekkür ederim.

\section{EXTENDED SUMMARY}

The beginning of terrestrial Neogene deposition in the northeastern coastal part of Çeşme Peninunsula is represented by the Sifne formation, 
which its lower contact is not observable. The succession reflects the Early Miocene deposition sensu lato. Its uppermost part is composed of lacustrine limestone with fresh water algae. Deposition of felsic ignimbrites (Alaçatı tuff), early products of Armağandăgl volcanism, on the limestone platform, interrupted the early Miocene lacustrine sedimentation represented by the Sifne formation. The equivalents of the Şifne formation in the coastal Aegean region are the Zeytindağ formation (Kaya, 1979) in the Foça Peninsula and the Yeniliman limestone (Göktaş, 2014a) in the Karaburun Peninsula.

In the study area, continuations of the Armağandă̆l volcanics (Türkecan et al., 1998), which represent the early Miocene-early Middle Miocene kalkalkaline volcanism in the Çeşme Peninsula, mainly consist of volcaniclastics. This volcaniclastic assemblage divided into two level, the Alaçatı tuff in the lower part characterized by felsic pyroclastics and the Reisdere volcaniclastics (Göktaş, 2010) composed of the products of andesitic volcanism in the upper part. Zeytineli formation (Göktaş, 2010) is the lava facies of the Armağandağl volcanics. The Alaçatı tuff, which is located between the Sifne formation and Reisdere volcaniclastics stratigraphically, represents the early phase of the Armăgandă̆ volcanism. The succession is composed of whitish light gray colored pyroclastics, and consists of mainly ignimbrite and some base surge and ash fall deposits. The abundant coarse andesite clasts with porphiric texture in the ignimbrites give an idea that an intermediate volcanism developed before the acidic volcanism. The Reisdere volcaniclastics is generally composed of levels of ignimbrite, blocky ash flow and lahar levels originated from an andesitic volcanism. It is announced that the lavas of Zeytineli formation, had a composition is mainly andesitic and partly dacitic in the previous works (Innocenti and Mazzuoli, 1972; Türkecan et al., 1998; Helvacr et al., 2009; Göktaş, 2010). The black colored andesites, which represent the Zeytineli formation in the study area, form the volumetrically largest part of the intermediate lavas in the Armăgandă̆ volcanics.

The Ildir formation (Göktaş, 2010) overlies the pre-Neogene basement rocks with an angular unconformity. The lavas and volcaniclastics of Armăgandağl volcanics and the Ildir formation, which are interfingered each other, represent the early Middle Miocene sedimentation and kalkalkaline volcanism in the study area. The Ildir formation is composed of Belentepe member, a fan delta deposit, in the lower part, and lacustrine deposits in the upper part, which overlies the lower one with a gradationally and partly interfingered contact. Debris flow deposits consisting of disorganized cobbles are dominant in the Belentepe member. Lacustrine sequence of the Ildir formation, which grades from mudstones up to limestones, laterally intercalates with Belentepe member and Reisdere volcaniclastics. Lacustrine deposition interrupted covering by the Reisdere volcaniclastic sheets. The Çiftlik formation (Göktaş, 2010) in Çeşme Peninsula and Hisarcı formation (Göktaş, 2014a,b) in the north of Karaburun Peninsula are possible equivalents of Ildir formation.

A synsedimentary black colored andesite lava flow in the Belentepe member is dated

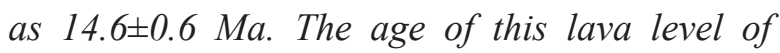
Zeytineli formation is the youngest age obtained from the Armağandağ $\mathrm{l}$ volcanism and it shows that kalkaline volcanism in the Çeşme Peninsula continued during the early Middle Miocene. 


\section{DEĞİNILEN BELGELER}

Altunkaynak, Ş., Rogers, N.W., Kelley S.P. 2010. Causes and effects of geochemical variations in late Cenozoic volcanism of the Foça volcanic centre, NW Anatolia, Turkey. International Geology Review 52, 579-607.

Bellon, H., Grisollet, G., Sorel D. 1979. Age de l'activité volcanique néogéne de l'ile de Chios (Mer Egée, Gréce). Comptes Rendus de l'Académie des Sciences, Série D, 288, 1255-1258.

Besenecker, H., 1973, Neogen und Qartär der Insel Chios (Ägäis): $\mathrm{PhD}$ Thesis, Freien Universität Berlin, $195 \mathrm{p}$.

Blikra, L. H. ve Nemec, W. (1998).Postglacial colluvium in western Norway: depositional processes, facies and palaeoclimatic record. Sedimentology, 45(5), 909-959.

Borsi, S., Ferrara, C., Innocenti, F., Mazzuoli, R. 1972. Geochronology and petrology of recent volcanics of Eastern Aegean Sea. Bulletin of Volcanology 36, 473-496.

Çakmakoğlu, A. ve Bilgin, Z.R. 2006. Karaburun Yarımadası'nın Neojen öncesi stratigrafisi, Maden Tetkik ve Arama Dergisi 132, 33-62.

Çakmakoğlu, B., Göktaş, F., Demirhan, M., Helvacı, C. 2013. Karaburun Yarımadası'nın kuzey kesimindeki killerin stratigrafisi, sedimantolojisi ve ekonomik kullanım olanaklarının araştırılması. Türkiye Jeoloji Bülteni 56/1, 39-58.

Emre, Ö., Özalp, S., Doğan, A., Özaksoy, V., Yıldırım, C., Göktaş, F. 2005. İzmir yakın çevresinin diri fayları ve deprem potansiyelleri. Maden Tetkik ve Arama Genel Müdürlügü Rapor No: 10754, 80 s, Ankara (yayımlanmamış).

Gemici, Ü. ve Filiz, Ş. 2001. Hydrochemistry of Çeşme geothermal area in western Turkey. Journal of Volcanology and Geothermal Research 110, 171187.

Göktaş, F. 2010. Çeşme Yarımadası'ndaki Neojen tortullaşması ve volkanizmasının jeolojik etüdü. Maden Tetkik ve Arama Genel Müdürlüğ̈̈ Rapor No: 11389, 64 s. Ankara (yayımlanmamış).

Göktaş, F. 2011. Urla (İzmir) çöküntüsündeki Neojen tortullaşması ve volkanizmasının jeolojik etüdü. Maden Tetkik ve Arama Genel Müdürlüğü Rapor No: 11568, 112 s. Ankara (yayımlanmamış).
Göktaş, F. 2014a. KaraburunYarımadası kuzeyindeki Erken Miyosen tortullaşması ve volkanizmasının stratigrafisi. Maden Tetkik ve Arama Dergisi 148, 43-61.

Göktaş, F. 2014b. Karaburun (İzmir) çevresinin Neojen stratigrafisi ve paleocoğrafik evrimi. Maden Tetkik ve Arama Dergisi 149, 71-94.

Göktaş, 2016. İzmir -Dış- Körfezi'ndeki adaların Neojen stratigrafisi. Maden Tetkik ve Arama Dergisi 152, 1-24.

Helvac1, C., Ersoy, Y., Sözbilir, H., Erkül, F., Sümer, Ö., Uzel, B. 2009. Geochemistry and ${ }^{40} \mathrm{Ar} /{ }^{39} \mathrm{Ar}$ geochronology of Miocene volcanic rocks from the Karaburun Peninsula: Implications for amphibole-bearing lithospheric mantle source, Western Anatolia. Journal of Volcanology and Geothermal Research 185, 181-202.

Innocenti, F. ve Mazzuoli, R. 1972. Petrology of İzmirKaraburun volcanic area (West Turkey). Bulletin of Volcanology 36, 83-104.

Irvine, T.N. ve Baragar, W.R.A. 1971. A guide to the chemical classification of the common volcanic rocks. Canadian Journal of Earth Sciences 8, 523 548.

Kaçmaz, H. ve Köktürk, U. 2004. Geochemistry and mineralogy of zeolitic tuffs from the Alaçat (Çeşme) Area, Turkey. Clays and Clay Minerals $52 / 6,705-713$

Kalafatçıŏlu, A. 1961. Karaburun Yarımadası'nın jeolojisi, Maden Tetkik ve Arama Dergisi 56, 5363.

Karacık, Z., Genç, Ş.C., Gülmez, F. 2013.Petrochemical features of Miocene volcanism around the Çubukludağ graben and Karaburun Peninsula, western Turkey: Implications for crustal melting related silicic volcanism. Journal of Asian Earth Sciences 73, 199-217.

Kaya, O. 1979. Orta Doğu Ege çöküntüsünün (Neojen) stratigrafisi ve tektoniği. Türkiye Jeoloji Kurumu Bülteni 22(1), 35-58.

Koufos, G.D. 2006. The Neogene mammal localities of Greece: Faunas, chronology and biostratigraphy. Hellenic Journal of Geosciences 41, 183-214.

Le Maitre, R.W. (Ed.) 2002. Igneous Rocks: A Classification and Glossary of Terms. Recommendations of the International Union of Geological Sciences Subcommission on 
the Systematics of Igneous Rocks. Cambridge University Press. 236 s.

Le Bas, M.J., Le Maitre, R.W., Streckeisen, A., Zanettin, B. 1986. A chemical classification of volcanic rocks based on total alkali-silica diagram. Journal of Petrology 27, 745-750.

Nemec, W., Kazanc1, N., Mitchell, J.G. 1998. Pleistocene explosions and pyroclastic currents in West-central Anatolia. Boreas 27, 311-332.

Nemec,W. ve Kazanc1,N. 1999. Quaternary colluvium in West-central Anatolia: sedimentary facies and palaeoclimatic significance. Sedimentology 46, 139-170.
Rickwood, P.C. 1989. Boundary lines within petrologic diagrams which use oxides of major and minör elements. Lithos 22, 247-263.

Türkecan, A., Ercan, T., Sevin, D. 1998. Karaburun Yarımadası'nın Neojen volkanizması. Maden Tetkik ve Arama Genel Müdürlüğ̈̈ Rapor No: 10185.

Makale Geliş Tarihi : 19 Temmuz 2016

Kabul Tarihi : 3 Ağustos 2016

Received : 19 July 2016

Accepted : 3 August 2016 
